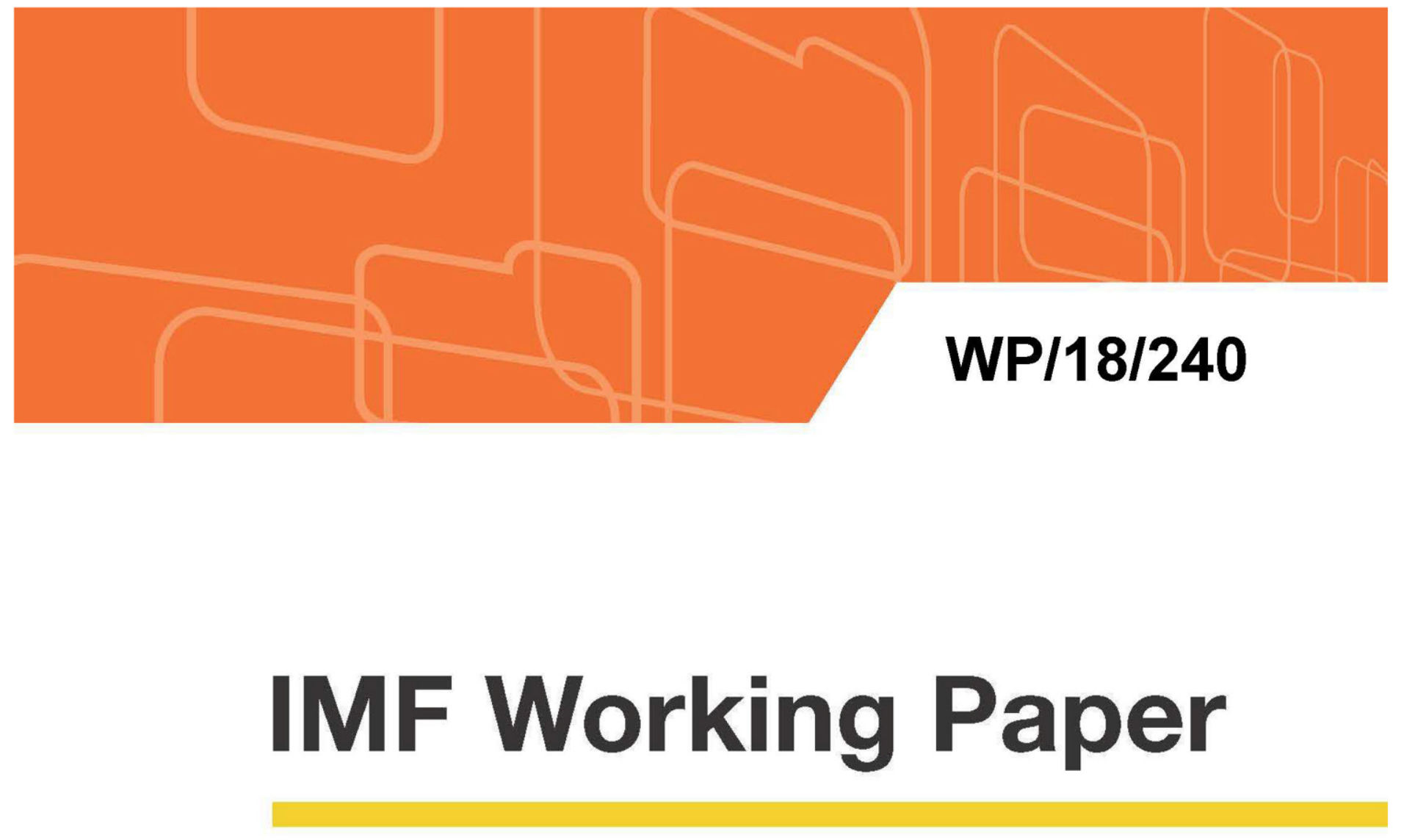

\title{
The Price and Welfare Effects of The Value-Added Tax: Evidence from Mexico
}

by Rodrigo Mariscal and Alejandro Werner

IMF Working Papers describe research in progress by the author(s) and are published to elicit comments and to encourage debate. The views expressed in IMF Working Papers are those of the author(s) and do not necessarily represent the views of the IMF, its Executive Board, or IMF management.

I N T E R N A T I O N A L M O N E T A R Y F 


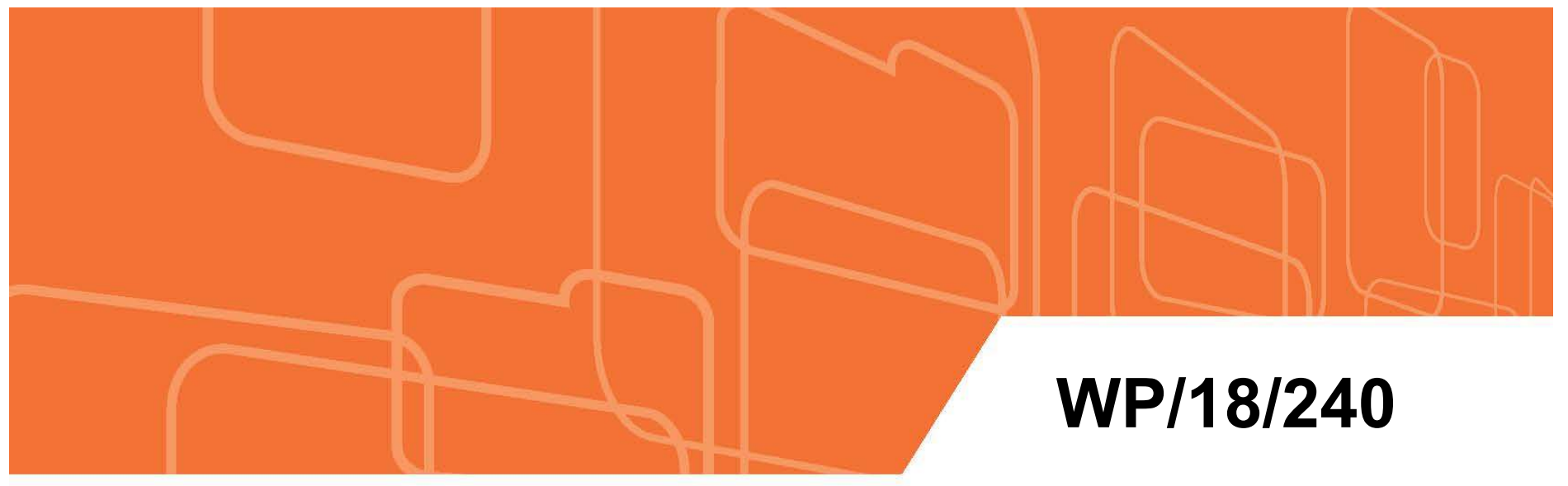

\section{The Price and Welfare Effects of The Value-Added Tax: Evidence from Mexico}

by Rodrigo Mariscal and Alejandro Werner

IMF Working Papers describe research in progress by the author(s) and are published to elicit comments and to encourage debate. The views expressed in IMF Working Papers are those of the author(s) and do not necessarily represent the views of the IMF, its Executive Board, or IMF management.

I N T E R N A T I O N A L M O N E T A R Y F 


\title{
IMF Working Paper
}

Western Hemisphere Department

\begin{abstract}
The Price and Welfare Effects of The Value-Added Tax: Evidence from Mexico ${ }^{1}$ Prepared by Rodrigo Mariscal and Alejandro Werner
\end{abstract}

Authorized for distribution by Alejandro Werner

November 2018

\begin{abstract}
IMF Working Papers describe research in progress by the author(s) and are published to elicit comments and to encourage debate. The views expressed in IMF Working Papers are those of the author(s) and do not necessarily represent the views of the IMF, its Executive Board, or IMF management.
\end{abstract}

\begin{abstract}
In this paper we analyze the incidence of the VAT and its effects on the income distribution. To identify these effects, we rely on two tax reforms undertaken in Mexico that increased the VAT rate for a group of cities and left the rest unaffected. We compare the inflation rate of the affected cities with the exempted cities before and after the law changed. We find that the effect on prices is limited and conclude that the burden of the tax is indeed shared between producers and consumers. Regarding welfare, we find that the VAT is progressive in both absolute and relative terms to the overall expenditure. Finally, we show that an identical change in the VAT rate when inflation is high and persistent doubles its pass-through to inflation and its welfare loss for the average household.
\end{abstract}

JEL Classification Numbers: H22, E31, C23.

Keywords: Value-Added Tax, Tax Incidence, Economic Welfare, Inflation Pass-Through, Difference-in-differences.

Author’s E-Mail Address: rmariscal@iif.com; rmariscal@colmex.mx; awerner@imf.org.

${ }^{1}$ We wish to thank Suman Basu, Francesca Caselli, and Nicolás Magud for their comments on an earlier draft. 
I. Introduction $\ldots \ldots \ldots \ldots \ldots$

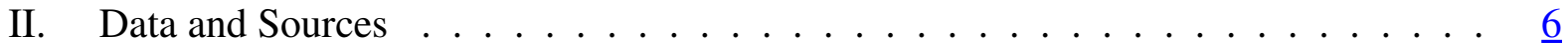

III. Estimation of the Pass-Through from Changes in the Rates of the VAT to Inflation . $\underline{8}$

A. The Difference in Differences Estimation . . . . . . . . . . . . . $\underline{9}$

B. The Difference in Differences Estimation from a Bottom-Up Approach . . . . 17

IV. Distribution and Welfare Effects of the VAT Reforms . . . . . . . . . . . . . 21

A. Estimation of a Quadratic Almost Ideal Demand System . . . . . . . . . . . $\underline{21}$

B. The Measurement of Welfare Loss . . . . . . . . . . . . . . . . . . 24

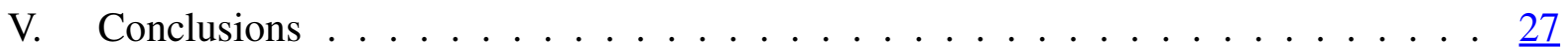

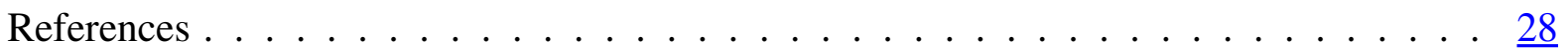

Appendices

A. Regression Results . . . . . . . . . . . . . . . . . .

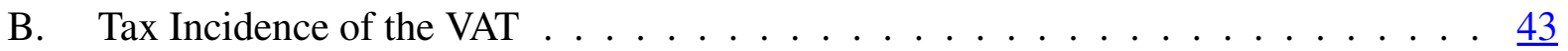

C. VAT with a Monopolistic Firm .................. 44

Tables

1. Summary Statistics: Monthly Inflation (NSA) . . . . . . . . . . . . 12

2. Summary Statistics: Monthly Inflation . . . . . . . . . . . . . . . . 12

3. Extended DID on Inflation and CD Test . . . . . . . . . . . . . . 15

4. Simple DID on Inflation . . . . . . . . . . . . . . . . . . 16

5. DID Bottom-Up Effect of VAT on Inflation by Type of Expense . . . . . . . . . . 19

6. DID Bottom-Up Effect of VAT on Inflation's Components . . . . . . . . . . . . . $\underline{20}$

7. DID Bottom-Up Effect of VAT on Inflation by VAT-Regime . . . . . . . . . . . 20

8. Expenditure Shares by Deciles . . . . . . . . . . . . . . . 23

9. Estimated Income and Own-Price Elasticities . . . . . . . . . . . . . 24

10. Distribution of Welfare Loss by Deciles . . . . . . . . . . . . . . . . 26

Figures

1. Historical Changes in the VAT and Location of Cities with CPIs . . . . . . $\underline{5}$

2. Distribution of Monthly Inflation (NSA) Rate . . . . . . . . . . . . . . . . . . . . . . . . .

3. Distribution of Monthly Inflation Rate . . . . . . . . . . . . . . . . 14

4. DID Estimates of VAT Pass-through . . . . . . . . . . . . . . 16

5. Distribution of Welfare Loss by Deciles . . . . . . . . . . . . $\underline{26}$ 


\section{INTRODUCTION}

Two important dimensions of indirect tax reforms are the effects that tax changes have on prices and on income distribution. The VAT is an indirect tax that is widely used and has gained more importance as a source of government revenue. As Bird and Gendron (2007) show, about 136 countries in the world have some type of VAT. In Latin America, the VAT is close to 30 percent of the tax revenue. ${ }^{1}$ Among other indirect taxes such as turnover and sales tax, the VAT has an advantage because it is both easy to administer and is less distortionary. Therefore, to strengthen its design and to implement compensatory measures it is essential to understand the economic effects of VAT reforms.

However, it is difficult to identify the effect of tax reforms such as the VAT on prices because they happen only so often, and during that window, prices are also affected by other factors. In the absence of an ideal setup, we exploit the structure of the VAT law in Mexico and the data available to identify the effect of the VAT on inflation.

The VAT was enacted by Congress in January of 1979. From the beginning, the structure of the VAT has been exceptional as it differentiates both regions and goods. For our purpose, the most important feature is the distinction between the general VAT rate and the border-city rate ${ }^{2}$. Figure 1a shows the changes in the general VAT rate and the border-city rate over time. Our identification strategy focuses on two VAT reforms that affected one of the rates but left the other one unchanged. The first one was in March of 1995 when the general rate was increased from 10 to 15 percent without including the border cities. The second one was in January of 2014 when the VAT on the border cities went from 11 to 16 percent without affecting the general VAT rate.

The next important data series that we use is the consumer price indexes (CPIs). Since January of 1990, Mexico's statistical agency (INEGI) publishes data on consumer prices by city. Figure 1c shows the location of the 46 cities with CPIs and identifies the border and non-border cities that the survey covers. With these two pieces of information, we split the sample between the border and the non-border cities, set inflation as our variable of interest, and subtract the average change of one group from the average change of the other. This method is known as difference in differences (DID). ${ }^{3}$

\footnotetext{
${ }^{1}$ See Bird and Gendron (2007) Table 2.3 on page 17 and Table 2.4 on page 18.

${ }^{2} \mathrm{~A}$ border city is one located inside the border zone that covers a $20 \mathrm{~km}$ stripe along the north and south borderline, two municipalities (Caborca and Cananea), three states (Quintanta Roo, Baja California Norte and Baja California Sur) and a small region in the state of Sonora that goes from the borderline to Puerto Peñasco.

${ }^{3}$ See, as a reference, Ashenfelter and Card (1985) and Card and Krueger (1994).
} 
This study goes beyond the work in Aportela and Werner (2002), who used the same approach to estimate the incidence of the VAT reform in 1995. Now in addition to the 1995 reform, we look at the effects of the most recent reform passed in 2014 and estimate the effect of the VAT on inflation; the subsequent impact on households' expenditure; and the associated change in welfare by deciles of income. We also show that the DID estimation can be made more robust to serial correlation and cross-sectional dependence.

As it has been documented in the literature, a change in VAT rate does not have a full passthrough to prices, and its change has varied effects on prices of different goods. For example, Politi and Mattos (2011) show that there is an asymmetric response in the prices of the commodities after a VAT reform in Brazil, and a full pass-through is rare in most of the cases. A similar conclusion came from Carare and Danninger (2008) in Germany, Kosonen (2015) in Finland, Gaarder (2016) in Norway, Banzarti and Carloni (2017) in France, and Benedek and others (2015) for the Eurozone. In all these cases, the pass-through is limited, and the consumers do not bear the full tax. This is a crucial result that any assessment of welfare should consider.

For the welfare analysis, King (1983) shows how to use a system of demand equations and its value function to measure changes in welfare. Following this approach, we estimate a system of demand equations using Mexico's 2010 Household Survey and show that the demand equations of all goods and services respond negatively to increases in prices. Food, beverages and clothing demand react like a necessity, with proportionally lower demand elasticity from high-income households. Meanwhile, the demand elasticity for schooling, furniture, and cultural activities are positively related to household income and grows when the household's incomes grow.

In terms of welfare, we find that the effect of the two reforms (April 1995 and January 2014) was negative and progressive. That is, households with higher income tend to pay more, both in absolute and relative terms. The explanation of this result lies in the uneven pass-through of the VAT to the CPI components, the consumption patterns of the households, and the fact that significant share of the consumption basket of the lowest deciles is subject to a zero VAT rate.

The rest of the paper is organized as follows. Section II shows how the variables are calculated and describes the sources. Then, Section III shows and discusses the DID estimations for the case of the VAT reforms undertaken in 1995 and 2014. Section IV presents the estimation of the demand functions and shows the calculations of the welfare effects of the two VAT reforms. Finally, Section V concludes. 
Figure 1. Historical Changes in the Value-Added Tax and Location of the Cities with CPIs

(a) Value-Added Tax Rate (Percentage points)

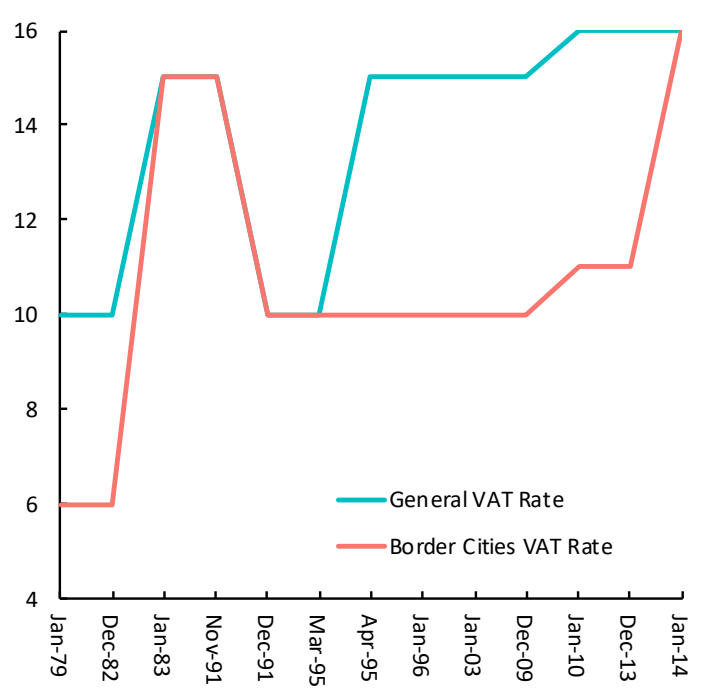

(b) Value-Added Tax Revenue (Percent of GDP)

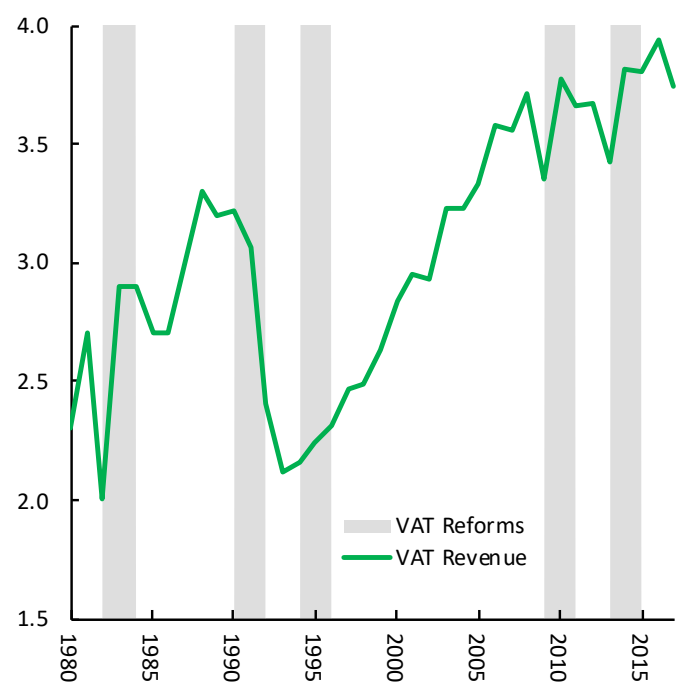

(c) Location of Cities with Consumer Price Indexes

(Border and Non-border Cities)

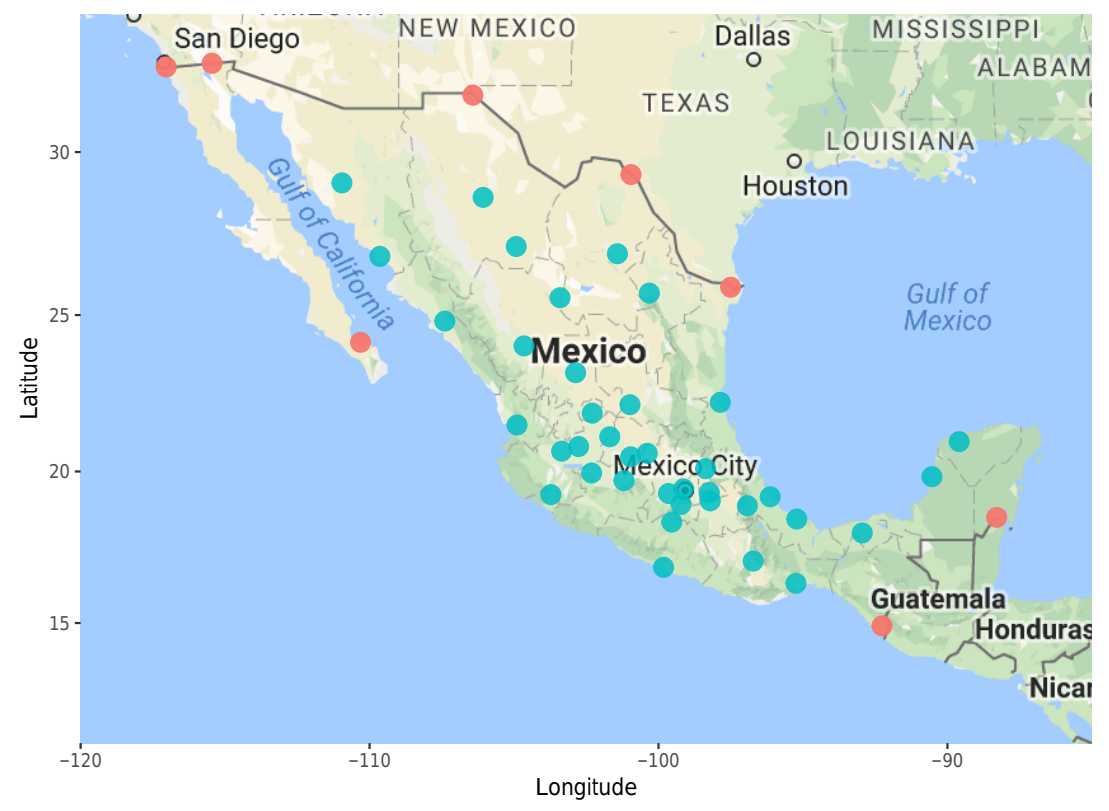

Sources: Value-Added Tax Law, Ministry of Finance (SHCP), INEGI, Google Maps and authors' calculations.

Border Cities: Cd. Acuña, Cd. Juárez, Chetumal, La Paz, Matamoros, Mexicali, Tapachula, Tijuana.

Non-Border Cities: Acapulco, Aguascalientes, Distrito Federal, Campeche, Cd. Jiménez, Colima, Córdoba, Cortázar, Cuernavaca, Culiacán, Chihuahua, Durango, Fresnilllo, Guadalajara, Hermosillo, Huatabambo, Iguala, Jacona, León, Mérida, Monclova, Monterrey, Morelia, Oaxaca, Puebla, Querétaro, San Andrés Tuxtla, San Luis Potosí, Tampico, Tehuantepec, Tepatitlán, Tepic, Tlaxcala, Toluca, Torreón, Tulancingo, Veracruz, Villahermosa. 


\section{DATA AND Sources}

This section presents the data used in this paper. Namely, two databases were used: the consumer price index (CPI) by city and by subclass-product; and the Household Survey of 2010 with information on income and expenditure.

\section{Prices and Inflation}

Prices and inflation are measured using the CPI of the 46 cities in the sample and its 283 categories of expenditure (subclass-product). The base period is the second half of December 2010, and the series are monthly from January of 1990 to April 2017. The data come from the web page of Mexico's statistics agency, INEGI (www.inegi.org.mx). The price series are adjusted for seasonality using ARIMA X-12 under the additive option applied to the first difference of the logarithm of the price index. Then, the seasonally adjusted variable in levels is recovered as the sum of the seasonally adjusted log-difference plus the first observation of the non-seasonal adjusted index, that is: $p_{t}^{\mathrm{sa}}=p_{0}^{\mathrm{nsa}}+\sum_{s=1}^{t} \Delta p_{s}^{\mathrm{sa}}$.

The inflation rate used for the estimations is the month-to-month percent change of the seasonally adjusted price index and non-seasonally adjusted.

To capture the cross-section dependence of inflation across cities, we use a proxy variable. This proxy variable is the cross-city average of the inflation rates weighted by the inverse of the distance between cities. Our objective is to capture the linkages between cities in a way that the cities that are nearer get more importance.

Let this proxy variable be defined as $\pi_{i t}^{\mathrm{CS}}=\boldsymbol{\omega}_{i}^{\prime} \boldsymbol{\pi}_{t}$, where $\pi_{t}$ is a $46 \times 1$ vector of inflation rates of the 46 cities in time $t$ and $\boldsymbol{\omega}_{i}$ is a normalized weight vector $(46 \times 1)$ using the inverse of the Euclidean (linear) distance from city $i$ to the rest of the $j$ cities. ${ }^{4}$ This variable is calculated for each of the 46 cities using the other 45 cities.

\footnotetext{
${ }^{4}$ The Euclidean distance is calculated using the latitude and longitude coordinates for each city (shown in Figure 1c) using the formula $D(i, j)=\sqrt{\left(\text { Lonitude }_{j}-\text { Lonitude }_{i}\right)^{2}+\left(\text { Latitude }_{j}-\text { Latitude }_{i}\right)^{2}}$.
} 


\section{Household Expenditure Survey}

For the estimation of the household's welfare loss, we use the 2010 Household Expenditure Survey. This database is available at INEGI's website and documented in INEGI (2011). Using this database, we build a new database that gathers the households' aggregate expenditure by each component of the CPI. 567

These calculations must be approached with some caution because it is well known that some expenses in the survey are understated (e.g., liquor, cigarettes, and beer); and for some goods, the expenses are reported as zero - although, we take this last issue into account with a censored regression model.

\footnotetext{
${ }^{5}$ The database compiles all the survey files from the source in one unique file. The survey files include household characteristics, quarterly expenses, monthly expenses, daily expenses, expense on education, utilities, and claimable rent.

${ }^{6}$ Every expenditure code in the household survey is mapped to the CPI's components. Then, all these expenses are aggregated to get the household's total expenditure per CPI component. INEGI (2011) Annex V, page 111118 , describes in detail the correspondences from the 2010 Survey to the CPI subclasses.

${ }^{7}$ The CPI expenditure household database is finally merged with the pass-through estimations of the 1995 and 2014 VAT Reforms. We use this final database to estimate the system of demand equations and the welfare effects of the VAT. The levels of aggregation are compatible with the Harmonized Indexes of Consumer Prices (HICP) used by other countries and international agencies, see http://www.ilo.org/public/english/bureau/stat/ guides/cpi/index.htm.
} 


\section{Estimation of the Pass-Through from Changes in THE RATES OF THE VAT TO INFLATION}

This section presents the standard difference in differences (DID) methodology applied to the VAT reforms of 1995 and 2014. Our objective is to quantify the effect of the five-percentagepoint increase in the VAT rate from these two reforms on the monthly inflation. The DID regression is a well-known approach to remove multivariate effects in the outcome that could bias the estimation of policy changes. In this case, the VAT reforms of 1995 and 2014 qualify as quasi-natural experiments because the tax change was applied to one group of cities and not the other, and the increase in the rate happened at the same time for all cities affected by the tax rate.

In 1995 the VAT rate was raised in the non-border cities from 10 to 15 percent. The measure was in response to the economic crisis, and the aim was to increase the tax revenues. In 2014, as a part of another tax reform, the VAT rate was raised on the border cities from 11 to 16 percent to increase the tax revenue after the sharp fall in oil prices. Previously, in 2010, the government intended to pass a uniform two percent expenditure tax, but Congress rejected that measure. In the end, Congress raised the overall VAT rate from 15 to 16 percent, and the rate in the border cities went from 10 to 11 percent. $^{8}$

There were other policies implemented at the time when the VAT reforms passed, especially in 1995 during the Mexican Crisis (see IMF Staff Reports for 1995 and 1996). We also note that other changes in the Tax Law passed beside the VAT rate change. For example, in 2014 the Government include pets, pet's food and bubble gum in the VAT when they used to be exempted; the same happened in 1995 with sweetened beverages (sodas and juices), caviar, and salmon. Then, in 1995 and 2010, the excise tax (IEPS) on beer, tobacco, and other alcoholic beverages was increased, and in 2010 levied for gambling games and telecommunications. And once again, in 2014, the excise tax was increased for sweetened beverages, high-calorie food, pesticides, and levied for carbon-producing products.

Despite all these changes and given that those policies were common to all cities, we assume that they affected every city in the same way or were small and immaterial. Thus, to a certain degree, the common effects across cities are removed with the DID, and only the VAT effect remains. To support this assumption, we show that the inflation rate across cites has common trends and a similar distribution both for the months before and after the VAT change. Then we

\footnotetext{
${ }^{8}$ The current VAT Law and all its previous changes are available in the Chamber of Deputies' web site, www. diputados.gob.mx/LeyesBiblio/ref/liva.htm.
} 
do a placebo test on the VAT reforms of 1991 and 2010 to show that the DID does not produce significant coefficients related to the VAT change.

\section{A. The Difference in Differences Estimation}

Table 1 and Table 2 show the summary statistics of inflation in border and non-border cities for seasonally and non-seasonally adjusted data. The descriptive statistics of the two groups match relatively well. Moreover, Figure 2 and Figure 3 show that the distributions broadly overlap and move in sync except in April of 1995 and January of 2014 when the VAT changes differ. These shifts and patterns are evidence that the two regions can be used as a counterfactual — we test this claim more formally later.

One problem in applications of panel data is the correlation of unobserved shocks across groups. For instance, trade between cities, regional factors, and spillovers could induce cross-correlation from one city to the others and bias the estimations; to control for this type of dependency, we include the cross-section inflation rate as a control. This variable is a weighted average of the inflation rates of all the cities, and the weights are proportional to the distance between them. ${ }^{9}$ The general equation form is the following:

$$
\pi_{i t}=\mu_{0}+\mu_{\mathrm{C}} D C_{i}+\mu_{\mathrm{T}_{j}} D T_{t+j}+\varphi_{j} D T_{t+j} \cdot D C_{i}+\theta \pi_{i t}^{\mathrm{CS}}+\varepsilon_{i t}
$$

where $\pi_{i t}$ is the monthly inflation rate, $D T_{t}$ is a dummy variable set to $\mathbb{1}$ at time $t$ when the VAT changed and zero otherwise; $D C_{i}$ is a dummy variable set to $\mathbb{1}$ on the city $i$ where the VAT changed and zero elsewhere. As previously described, $\pi_{i t}^{\mathrm{CS}}$ is the cross-section inflation of cities near city $i$, and finally, $\varepsilon_{i t}$ is the unobservable characteristics of the cities. To introduce anticipatory effects and second-round effects, we include $m$ leads and $q$ lags of the variable $D T_{t+j}(j=-q, \ldots, m)$, with six months of data before and after the actual date when the VAT set in. We use this sample to have more degrees of freedom and to be able to test for cross-sectional dependence. ${ }^{10}$

\footnotetext{
${ }^{9}$ For more detail on how we calculate this variable see the Section II.

${ }^{10}$ Note that this test needs enough mass of observations to calculate the correlations and produce reliable estimates. We also prove extending and shrinking the sample size, increasing the number of lags and allowing for different varying effects. In all cases the results were broadly the same. The full set of results are shown in the Appendix A.
} 
Our parameter of interest is $\varphi$, which captures the net effect of the VAT change on inflation once the unconditional mean $\mu_{0}$, the time effect $\mu_{\mathrm{T}}$, the group effect $\mu_{\mathrm{C}}$, and other controls are taken into account.

Table 3 shows the estimated effects of the two VAT reforms. The higher and most significant effect is precisely at the month when the VAT reforms are adopted. Only the 1995 reform has significant second-round effects. For this reform, the estimated effect is between 1.2 and 2.0 on April; that makes the elasticity of the VAT between 0.2 and 0.4 percentage points. Accumulating the significant months from April to June, the elasticity goes up to 0.6 percentage points. Meanwhile, for the 2014 reform, only January is significant, and the estimates give an elasticity between 0.14 and 0.19 percentage points.

The coefficients of the regressions that include the cross-section inflation are lower than the ones that do not. In comparison, all the non-seasonally adjusted regressions present high crosssectional dependence, as it is shown by CD Test (Pesaran, 2004) and the cross-correlation of the residuals (Table 3). These results are evidence, on the one hand, that inflation shocks are transmitted through geographical proximity; and, on the other, that there are strong seasonal patterns common to the cities that the DID cannot remove completely.

We believe that the change of coefficients over time is related to the level and persistence of inflation. In 1995, when Mexico's inflation was higher and more persistent than in 2014, the VAT's impact is higher and more persistent as well. This finding is consistent with Chiquiar, Noriega, and Ramos-Francia (2010) who estimate a reduction in the persistence of inflation set in January of 2001. Similarly, Schmidt-Hebbel and Werner (2002) and Mariscal, Powell, and Tavella (2018) show that since the adoption of inflation targeting, the Central Bank of Mexico has improved its credibility and dilute the effect of inflation's shocks on inflation's expectations.

Having said that, not all the pass-through reduction comes from the price stabilization. We find that part of the reduction is because the cities near the border face higher competition - in particular, those at the northern board. To get a sense of how much of the effect comes from price stabilization and how much from the asymmetric response of the regions to the VAT rate, we estimate the DID regressions with a sample that excludes the center cites and balances the north with the southern cities, and a sample that excludes the northern region for VAT reform of 2014.

We find that the coefficients on the regressions that exclude the center cites are lower than the regressions that include all the cities available (Appendix Table 5 and Appendix Table 7). Conversely, the coefficients in the sample that excludes the northern cities are higher than the 
coefficients in the sample that includes all cities (Appendix Table 8). Therefore, we estimate that the net reduction of the pass-through from 1995 to 2014 is about one percentage point instead of 1.3 that the full sample brings. However, this method of analysis has limitations. One needs to note that in the second set that excludes the northern cities, there are only two border cities to compare with the rest. This downsize in the number of cities reduces the confidence level and increases the margin of error.

As a point of comparison, we show in Table 4 and Figure 4 the results of the simple DID regression without the cross-section inflation and the pre/post-effects as controls. These estimates get the simple VAT effect of one month at the time but disregard the monthly effect of the VAT combined. That is, the regressions catch the effects per month unconditionally, instead of the effect of the current month conditional on the last and the next months. Note that the magnitudes of the coefficients are not widely different from Table 3. However, one needs to keep in mind that the simple DID overestimate the effect on the switching date and underestimate the effects outside this date.

Finally, we turn to a placebo test to check the assumption that the border and non-border cities are good counterfactuals. The idea is to show that a simultaneous VAT change in both border and non-border cities would affect the outcome of both groups in the same way. If so, one could use either of the groups as counterfactuals. This test is done by estimating the DID regressions on the reforms of 2010 and 1991 when the VAT rate change for both groups. Ideally one should find the parameter of interest $(\varphi)$ to be insignificant.

The VAT effects of the border and the non-border cities are statistically insignificant in general (Appendix Table 3 and Appendix Table 4). However, the VAT reform of 2010 has a significant effect in January. Even after we exclude the center cities from the sample and add the crosssection inflation, the January effect remains significant (Appendix Table 6). In the next section, we will explore the composition of the effects and offer some explanations for this and other results shown in this section. 
Table 1. Summary Statistics: Monthly Inflation (NSA)

\begin{tabular}{|c|c|c|c|c|c|c|c|c|c|c|c|c|}
\hline \multirow[b]{2}{*}{ Dates } & \multicolumn{6}{|c|}{ Border Cities } & \multicolumn{6}{|c|}{ Non-Border Cities } \\
\hline & $\mathrm{N}$ & Mean & Std.Dev. & Median & Min & Max & $\mathrm{N}$ & Mean & Std.Dev. & Median & Min & Max \\
\hline Nov-91 & 7 & 2.07 & 0.37 & 2.03 & 1.43 & 2.48 & 28 & 2.15 & 0.48 & 2.08 & 1.37 & 3.15 \\
\hline Dec-91 & 7 & 2.02 & 0.43 & 2.26 & 1.46 & 2.48 & 28 & 2.11 & 0.36 & 1.99 & 1.57 & 2.94 \\
\hline Jan-92 & 7 & 1.63 & 0.30 & 1.56 & 1.33 & 2.25 & 28 & 1.68 & 0.24 & 1.61 & 1.31 & 2.44 \\
\hline Mar-95 & 8 & 5.71 & 0.94 & 5.50 & 4.55 & 7.53 & 38 & 5.45 & 0.73 & 5.26 & 4.44 & 7.39 \\
\hline Apr-95 & 8 & 6.58 & 0.36 & 6.53 & 6.08 & 7.11 & 38 & 7.85 & 0.78 & 7.84 & 6.51 & 9.79 \\
\hline May-95 & 8 & 3.58 & 0.60 & 3.54 & 2.89 & 4.34 & 38 & 4.05 & 0.37 & 4.04 & 3.32 & 4.95 \\
\hline Dec-09 & 8 & 0.27 & 0.18 & 0.31 & 0.04 & 0.51 & 38 & 0.36 & 0.20 & 0.35 & 0.05 & 0.71 \\
\hline Jan-10 & 8 & 0.89 & 0.23 & 0.83 & 0.67 & 1.28 & 38 & 1.16 & 0.43 & 1.07 & 0.37 & 2.44 \\
\hline Feb-10 & 8 & 0.34 & 0.35 & 0.40 & -0.44 & 0.65 & 38 & 0.53 & 0.28 & 0.51 & -0.22 & 1.41 \\
\hline Dec-13 & 8 & 0.42 & 0.26 & 0.43 & -0.06 & 0.86 & 38 & 0.47 & 0.31 & 0.44 & -0.20 & 1.25 \\
\hline Jan-14 & 8 & 1.77 & 0.41 & 1.67 & 1.36 & 2.45 & 38 & 0.82 & 0.38 & 0.78 & 0.12 & 1.72 \\
\hline Feb-14 & 8 & 0.08 & 0.36 & 0.05 & -0.51 & 0.64 & 38 & 0.22 & 0.25 & 0.19 & -0.41 & 0.83 \\
\hline
\end{tabular}

Sources: INEGI and authors' calculations.

Notes: Month-to-month percent change of the non-seasonally adjusted price index by city.

Table 2. Summary Statistics: Monthly Inflation

\begin{tabular}{|c|c|c|c|c|c|c|c|c|c|c|c|c|}
\hline \multirow[b]{2}{*}{ Dates } & \multicolumn{6}{|c|}{ Border Cities } & \multicolumn{6}{|c|}{ Non-Border Cities } \\
\hline & $\mathrm{N}$ & Mean & Std.Dev. & Median & Min & Max & $\mathrm{N}$ & Mean & Std.Dev. & Median & Min & Max \\
\hline Nov-91 & 7 & 1.55 & 0.33 & 1.50 & 1.17 & 1.96 & 28 & 1.79 & 0.46 & 1.71 & 1.18 & 2.82 \\
\hline Dec-91 & 7 & 1.30 & 0.30 & 1.37 & 0.87 & 1.70 & 28 & 1.39 & 0.33 & 1.27 & 0.89 & 2.22 \\
\hline Jan-92 & 7 & 1.15 & 0.21 & 1.07 & 0.95 & 1.57 & 28 & 1.12 & 0.22 & 1.10 & 0.72 & 1.82 \\
\hline Mar-95 & 8 & 5.66 & 0.89 & 5.68 & 4.58 & 7.42 & 38 & 5.47 & 0.80 & 5.27 & 4.38 & 7.49 \\
\hline Apr-95 & 8 & 6.33 & 0.41 & 6.47 & 5.69 & 6.79 & 38 & 7.91 & 0.78 & 7.95 & 6.43 & 9.93 \\
\hline May-95 & 8 & 3.95 & 0.83 & 3.91 & 2.98 & 5.64 & 38 & 4.28 & 0.37 & 4.25 & 3.31 & 5.11 \\
\hline Dec-09 & 8 & 0.21 & 0.19 & 0.26 & -0.03 & 0.44 & 38 & 0.18 & 0.18 & 0.21 & -0.17 & 0.47 \\
\hline Jan-10 & 8 & 0.49 & 0.24 & 0.39 & 0.28 & 0.93 & 38 & 0.92 & 0.43 & 0.79 & 0.30 & 2.13 \\
\hline Feb-10 & 8 & 0.40 & 0.20 & 0.42 & 0.15 & 0.71 & 38 & 0.53 & 0.25 & 0.51 & -0.11 & 1.20 \\
\hline Dec-13 & 8 & 0.33 & 0.25 & 0.32 & -0.04 & 0.82 & 38 & 0.32 & 0.23 & 0.32 & -0.14 & 0.93 \\
\hline Jan-14 & 8 & 1.27 & 0.78 & 1.02 & 0.59 & 2.77 & 38 & 0.56 & 0.31 & 0.49 & -0.02 & 1.25 \\
\hline Feb-14 & 8 & 0.16 & 0.17 & 0.16 & -0.05 & 0.45 & 38 & 0.18 & 0.21 & 0.20 & -0.31 & 0.72 \\
\hline
\end{tabular}

Sources: INEGI and authors' calculations.

Notes: Month-to-month percent change of the seasonally adjusted price index by city. 
Figure 2. Distribution of Monthly Inflation (NSA) Rate

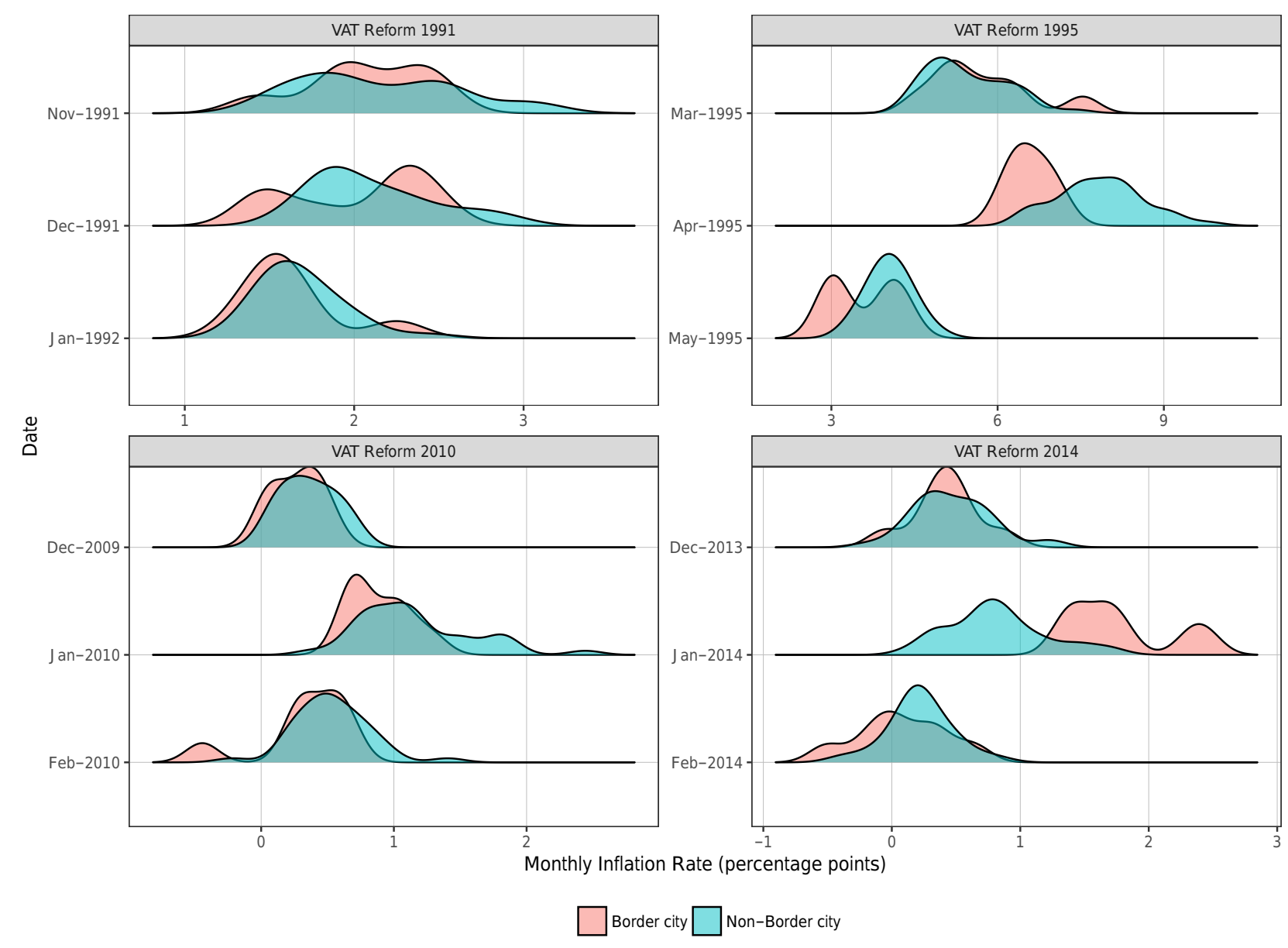

Sources: INEGI and authors' calculations.

Notes: Month-to-month percent change of the non-seasonally adjusted price index by city. Shapes display the Gaussian kernel density estimation. 
Figure 3. Distribution of Monthly Inflation Rate

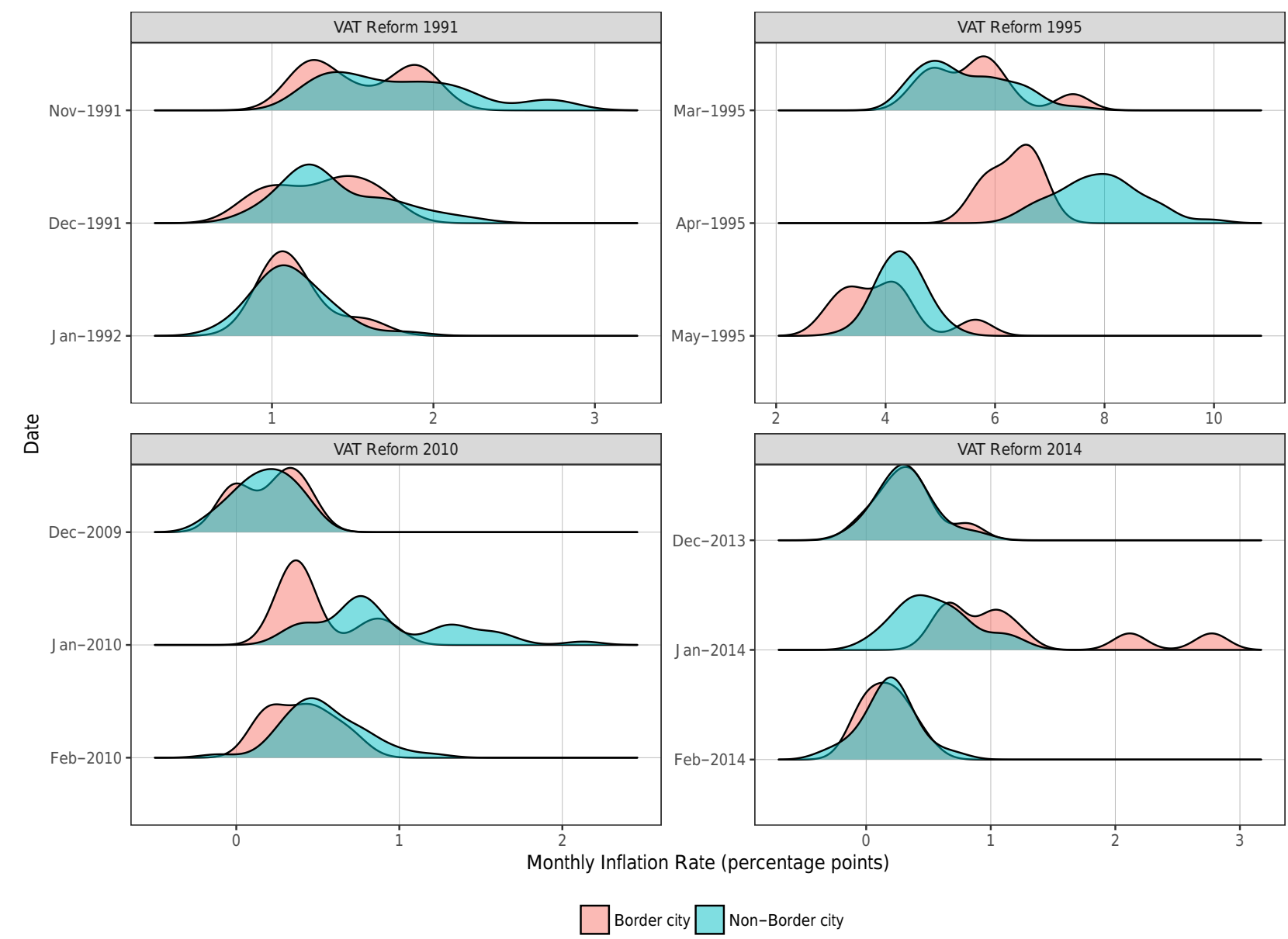

Sources: INEGI and authors' calculations.

Notes: Month-to-month percent change of the seasonally adjusted price index by city. Shapes display the Gaussian kernel density estimation. 
Table 3. Extended DID on Inflation and CD Test

\begin{tabular}{|c|c|c|c|c|}
\hline & Inflation (NSA) & $\begin{array}{c}\text { Inflation (NSA) } \\
\text { CS-Inflation }\end{array}$ & Inflation & $\begin{array}{c}\text { Inflation } \\
\text { CS-Inflation }\end{array}$ \\
\hline \multirow[t]{2}{*}{ VAT 1995 (Mar) } & -0.097 & -0.152 & 0.120 & 0.150 \\
\hline & $(0.342)$ & $(0.333)$ & $(0.391)$ & $(0.432)$ \\
\hline \multirow[t]{2}{*}{ VAT 1995 (Apr) } & $1.436^{\star \star *}$ & $1.218^{\star \star \star}$ & $1.888^{\star \star *}$ & $1.987^{\star \star *}$ \\
\hline & $(0.199)$ & $(0.207)$ & $(0.369)$ & $(0.413)$ \\
\hline \multirow[t]{2}{*}{ VAT 1995 (May) } & $0.637^{* * *}$ & $0.537^{* *}$ & $0.636^{* * *}$ & $0.688^{* * *}$ \\
\hline & $(0.236)$ & $(0.239)$ & $(0.240)$ & $(0.263)$ \\
\hline \multirow[t]{2}{*}{ VAT 1995 (Jun) } & $0.427^{\star *}$ & $0.376^{\star *}$ & $0.682^{\star *}$ & $0.734^{\star *}$ \\
\hline & $(0.172)$ & $(0.189)$ & $(0.302)$ & $(0.354)$ \\
\hline CD Test & $72.27^{\star * \star}$ & $14.81^{* \star *}$ & $64.15^{\star \star \star}$ & $10.32^{* * *}$ \\
\hline Avg.Rho CSD & 0.62 & 0.13 & 0.55 & 0.09 \\
\hline BGW Test & $340.59^{* * *}$ & $238.75^{\star * *}$ & $327.67^{\star * *}$ & $266.03^{* * *}$ \\
\hline \multirow[t]{2}{*}{ VAT 2013 (Dec) } & -0.053 & 0.022 & 0.026 & 0.027 \\
\hline & $(0.125)$ & $(0.144)$ & $(0.112)$ & $(0.121)$ \\
\hline \multirow[t]{2}{*}{ VAT 2014 (Jan) } & $0.952^{* * *}$ & $0.787^{* \star *}$ & $0.722^{* *}$ & $0.744^{* *}$ \\
\hline & $(0.154)$ & $(0.171)$ & $(0.281)$ & $(0.318)$ \\
\hline \multirow[t]{2}{*}{ VAT 2014 (Feb) } & -0.137 & -0.146 & -0.008 & -0.014 \\
\hline & $(0.147)$ & $(0.141)$ & $(0.062)$ & $(0.063)$ \\
\hline CD Test & $33.58^{* * *}$ & $3.04^{* * *}$ & $35.16^{\star * *}$ & -0.77 \\
\hline Avg.Rho CSD & 0.29 & 0.03 & 0.27 & 0.01 \\
\hline BGW Test & $191.48^{\star * *}$ & $178.11^{\text {***}}$ & $35.16^{\star \star \star}$ & 13.69 \\
\hline
\end{tabular}

Sources: INEGI and authors' calculations.

Notes: The full report of the difference in differences estimations is available in the Appendix A, Table 1 and Table 2. CS-Inflation: regression that includes weighted average cross-section inflation rate of the near cities defined in Section II. CD Test: Pesaran (2004) test for HO of cross-sectionally independent residuals. Avg. Rho CS: average correlation coefficient for cross-sectional dependence in panels. BGW Test: BreuschGodfrey-Wooldridge test for serial correlation in panel models, the null is that there is no serial correlation. Block-bootstrap standard errors in parentheses (correct for serial correlation), ${ }^{*} p<0.10,{ }^{* *} p<0.05,{ }^{* \star *} p$ $<0.01$. 
Table 4. Simple DID on Inflation

\begin{tabular}{lcc}
\hline \hline & Inflation (NSA) & Inflation \\
\hline VAT 1995 (Mar) & $0.519^{*}$ & $0.982^{\star * *}$ \\
& $(0.323)$ & $(0.207)$ \\
VAT 1995 (Apr) & $1.534^{* * *}$ & $1.768^{* * *}$ \\
& $(0.409)$ & $(0.382)$ \\
VAT 1995 (May) & $0.734^{*}$ & 0.516 \\
& $(0.418)$ & $(0.494)$ \\
VAT 1995 (Jun) & 0.525 & 0.562 \\
& $(0.387)$ & $(0.384)$ \\
\hline \multirow{2}{*}{ VAT 2013 (Dec) } & -1.348 & 0.096 \\
& $(1.12)$ & $(0.138)$ \\
VAT 2014 (Jan) & $1.005^{* * *}$ & $0.696^{* *}$ \\
& $(0.238)$ & $(0.315)$ \\
VAT 2014 (Feb) & -0.085 & -0.035 \\
& $(0.164)$ & $(0.119)$ \\
\hline \hline
\end{tabular}

Sources: INEGI and authors' calculations.

Notes: The full report of the difference in differences estimations is available in the Appendix A, Table 1 and Table 2. Block-bootstrap standard errors in parentheses (correct for serial correlation), ${ }^{*} p<0.10,{ }^{\star \star} p<0.05,{ }^{* \star \star} p<0.01$.

\section{Figure 4. DID Estimates of VAT Pass-through}

(a) Monthly Inflation Rate as of 1995 (Percentage points)

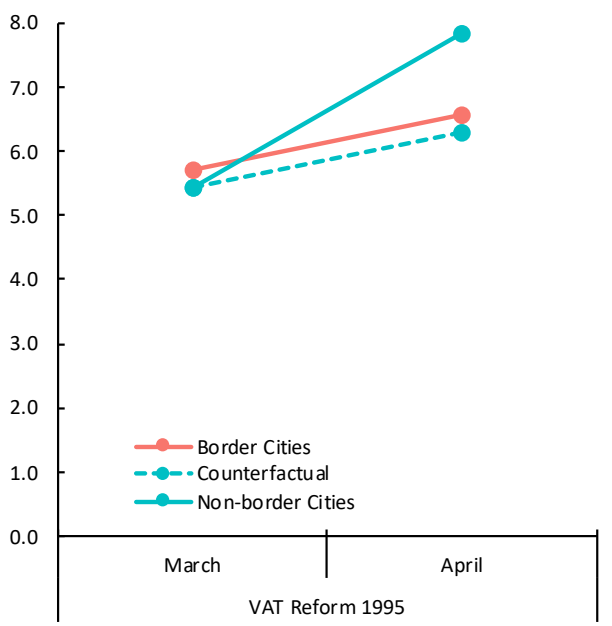

(b) Monthly Inflation Rate as of 2014 (Percentage points)

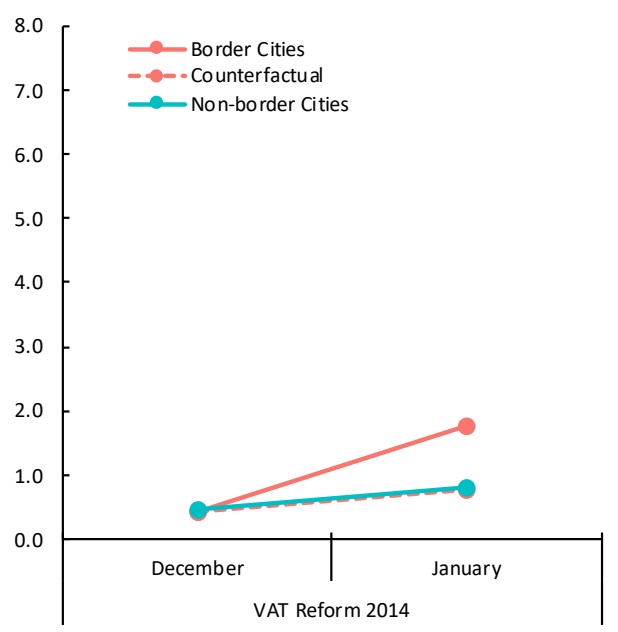

Sources: INEGI and authors' calculations.

Notes: The estimates come from a simple difference in differences model. The full report of the difference in differences estimations is available in the Appendix A, Table 1 and Table 2. 


\section{B. The Difference in Differences Estimation from a Bottom-Up Approach}

This section will show the details of the VAT reforms by looking at the subclass components of the CPI. The approach is the same as the previous Section III.A but now running the difference in difference (DID) regression for each of the 283 CPI subclass components. We use a mean group estimation to summarize our findings and aggregate the 283 components into twelve categories of expenses, three categories of VAT regimes, and six categories of inflation components.

Overall the results are consistent with the previous section. The pass-through from changes in the VAT rate to inflation has decreased between 1995 and 2014. Nonetheless, the composition of such a decrease has been mixed within the subclasses.

The first aggregation presented in Table 5 shows the DID estimates aggregated by twelve categories of expenditure. One can see that the pass-through of tradable goods, which has been more exposed to foreign competition coming from trade, has decreased over time. We refer specifically to alcoholic beverages, tobacco, clothing, furniture, and transportation (e.g., tires, bicycles, cars, and motorcycles). However, for the non-tradable goods like communications, healthcare, and schooling, the pass-through has increased. Communications, for example, has the highest increase in the mobile phone plans, home phone plans, and long-distance calls. Meanwhile, in the healthcare business, the highest increases were in general healthcare facilities, laboratory studies, and diabetes medication. For the rest of goods and services, the effect has been insignificant or without a substantial change over time.

The next aggregation presented in Table 6 shows the bottom-up effect on inflation's components. One can see that the primary driver of the overall effect is on core inflation. While the importance of core-merchandise has decreased over time, the core-services has increased and practically revert in magnitude. Again, this pattern suggests that merchandises have been more exposed to competition and the supply curve has become more elastic. Instead, core-services have kept its monopolistic power, but because the demand for these services has presumably increased, the effect of the VAT has increased as well. ${ }^{11}$

Finally, on the aggregation by VAT regime, Table 7 shows the mean group estimations. The effect on the taxed goods is, as one would expect, the highest and most significant. A fivepercentage-point increase in the VAT rate in 1995 increased the inflation rate of the VAT-taxed goods by more than two and a half percentage points giving a 50 percent pass-through; whereas, in 2014 , the effect is closer to one percentage point or a 20 percent pass-through.

\footnotetext{
${ }^{11}$ The intuition behind this analysis is provided in the Appendix C.
} 
One can see that the effect on the zero-rate goods is not significant, but the prices of goods and services under the exempt regime do show a significant effect. This significance happens because businesses selling zero-rate goods can claim a rebate against the VAT paid on its inputs. However, businesses selling exempt goods cannot claim a credit against the VAT paid on its inputs - the VAT adds to their costs and is non-refundable. Therefore, businesses with exempt goods are more prone to pass on the VAT to its final price, and so the effect of the VAT turns to be significant.

At the end of the previous Section III.A we checked if the border and non-border cities were good as counterfactuals. While the VAT reform of 1991 passed our placebo test, we found evidence against the VAT Reform of 2010 — specifically in January when the legislation entered. Using the same framework as in the previous section, we turn now to the disaggregated components. We find that the failure of the placebo test in January of 2010 is more the result of the surge in the prices of fuels, transportation, and government tariffs that coincides with the VAT change.

Most of the effect in the inflation rate arises from the non-core components of the CPI and broadly affected all the VAT-regimes (Appendix Table 9 and Appendix Table 10). Meanwhile, with the other VAT reforms, the higher and most significant effects were concentrated on the core components of the CPI and the taxed goods. Moreover, when we clear the sample to exclude the center cities, we find transportation services, energy prices, and government tariffs to be still significant, but agricultural goods and overall inflation not to be significant anymore.

We have shown the outcome of the VAT on inflation and its composition, but now the question is how these changes have affected the households' welfare. Before addressing the question, we need to define a measure of welfare and estimate a system of demand functions. Next section will take on these matters. 
Table 5. DID Bottom-Up Effect of VAT on Inflation by Type of Expense

\begin{tabular}{|c|c|c|c|c|c|}
\hline & \multirow[b]{2}{*}{ Count } & \multicolumn{2}{|c|}{ VAT 1995 (Apr) } & \multicolumn{2}{|c|}{ VAT 2014 (Jan) } \\
\hline & & Simple & CS-Inflation & Simple & CS-Inflation \\
\hline \multirow[t]{2}{*}{ 1. Food and non-alcoholic beverages } & 96 & 0.18 & -0.02 & -0.14 & -0.18 \\
\hline & & $(0.407)$ & $(0.373)$ & $(0.277)$ & $(0.241)$ \\
\hline \multirow[t]{2}{*}{ 2. Alcoholic beverages and tobacco } & 7 & $5.48^{* * *}$ & $5.18^{* * *}$ & $1.56^{\star *}$ & $1.57^{\star \star}$ \\
\hline & & $(0.630)$ & $(0.801)$ & $(0.511)$ & $(0.499)$ \\
\hline \multirow[t]{2}{*}{ 3. Clothing and footwear } & 29 & $2.93^{* * *}$ & $3.03^{\star * \star}$ & $0.62^{* \star \star}$ & $0.61^{* * *}$ \\
\hline & & $(0.443)$ & $(0.469)$ & $(0.180)$ & $(0.179)$ \\
\hline \multirow[t]{2}{*}{ 4. Housing and utilities } & 7 & $0.59^{*}$ & $0.33^{*}$ & $2.04^{*}$ & 1.45 \\
\hline & & $(0.267)$ & $(0.134)$ & $(0.910)$ & $(0.834)$ \\
\hline \multirow[t]{2}{*}{ 5. Furniture and house supplies } & 38 & $2.13^{\star \star \star}$ & $2.03^{* * *}$ & $1.09^{* * *}$ & $1.08^{* * *}$ \\
\hline & & $(0.384)$ & $(0.410)$ & $(0.351)$ & $(0.350)$ \\
\hline \multirow[t]{2}{*}{ 6. Health care } & 23 & $0.72^{*}$ & $0.73^{*}$ & $1.34^{\star \star *}$ & $1.35^{\star * *}$ \\
\hline & & $(0.395)$ & $(0.421)$ & $(0.319)$ & $(0.325)$ \\
\hline \multirow[t]{2}{*}{ 7. Transportation } & 18 & $2.87^{\star * *}$ & $2.20^{\star *}$ & 0.96 & $0.89^{*}$ \\
\hline & & $(0.883)$ & $(0.884)$ & $(0.561)$ & $(0.511)$ \\
\hline \multirow[t]{2}{*}{ 8. Communications } & 6 & 0.98 & 0.45 & $2.46^{\star \star}$ & $2.29^{\star \star}$ \\
\hline & & $(0.508)$ & $(0.455)$ & $(0.844)$ & $(0.778)$ \\
\hline \multirow[t]{2}{*}{ 9. Recreation and cultural activities } & 20 & $2.68^{\star * *}$ & $2.61^{* * *}$ & $0.96^{\star *}$ & $0.96^{\star *}$ \\
\hline & & $(0.831)$ & $(0.783)$ & $(0.409)$ & $(0.406)$ \\
\hline \multirow[t]{2}{*}{ 10. Schooling } & 8 & -0.04 & 0.03 & $0.20^{* * *}$ & $0.12^{\star *}$ \\
\hline & & $(0.166)$ & $(0.182)$ & $(0.044)$ & $(0.036)$ \\
\hline \multirow[t]{2}{*}{ 11. Restaurants and hotels } & 9 & 0.68 & 0.63 & 0.41 & 0.43 \\
\hline & & $(0.561)$ & $(0.441)$ & $(0.461)$ & $(0.410)$ \\
\hline \multirow[t]{2}{*}{ 12. Diverse goods and services } & 21 & $3.03^{* * *}$ & $2.99^{* * *}$ & $2.28^{* * *}$ & $2.25^{\star * *}$ \\
\hline & & $(0.732)$ & $(0.754)$ & $(0.528)$ & $(0.517)$ \\
\hline \multirow[t]{2}{*}{ Overall Inflation } & 282 & $1.50^{\star * *}$ & $1.36^{\star \star *}$ & $0.73^{\star * *}$ & $0.69^{\star * *}$ \\
\hline & & $(0.202)$ & $(0.197)$ & $(0.137)$ & $(0.126)$ \\
\hline
\end{tabular}

Sources: INEGI and authors' calculations.

Notes: Inflation is seasonally adjusted. Mean group estimation of the DID VAT effect per category: $\widehat{\varphi}=\frac{1}{N} \sum_{i} \widehat{\varphi}_{i}$, as in equation (III.1). The full report of the DID per category is available at the online repository. CS-Inflation: regression that includes weighted average cross-section inflation rate of the near cities defined in Section II. The estimates exclude subway transportation, thus number of subclasses is 282. Standard errors in parentheses: $S E(\widehat{\varphi})=\sqrt{\frac{1}{N(N-1)} \sum_{i}\left(\widehat{\varphi}_{i}-\widehat{\varphi}\right)^{2}}$, and p-values come from a t-distribution: * $\mathrm{p}<$ $0.10,{ }^{* *} p<0.05,{ }^{* * *} p<0.01$. 
Table 6. DID Bottom-Up Effect of VAT on Inflation's Components

\begin{tabular}{|c|c|c|c|c|c|}
\hline & \multirow[b]{2}{*}{ Count } & \multicolumn{2}{|c|}{ VAT 1995 (Apr) } & \multicolumn{2}{|c|}{ VAT 2014 (Jan) } \\
\hline & & Simple & CS-Inflation & Simple & CS-Inflation \\
\hline \multirow[t]{2}{*}{ Core } & 229 & $1.85^{\star * *}$ & $1.71^{\star * *}$ & $0.87^{\star * *}$ & $0.86^{\star * *}$ \\
\hline & & $(0.182)$ & $(0.188)$ & $(0.124)$ & $(0.119)$ \\
\hline \multirow[t]{2}{*}{ Merchandise } & 183 & $2.07^{\star \star \star}$ & $1.93^{\star \star *}$ & $0.68^{* * *}$ & $0.69^{\star \star *}$ \\
\hline & & $(0.210)$ & $(0.217)$ & $(0.131)$ & $(0.129)$ \\
\hline \multirow[t]{2}{*}{ Services } & 46 & $0.96^{* * *}$ & $0.87^{* *}$ & $1.65^{\star * *}$ & $1.57^{\star * *}$ \\
\hline & & $(0.325)$ & $(0.338)$ & $(0.302)$ & $(0.277)$ \\
\hline \multirow[t]{2}{*}{ Non-core } & 53 & 0.00 & -0.22 & 0.13 & -0.10 \\
\hline & & $(0.703)$ & $(0.631)$ & $(0.491)$ & $(0.423)$ \\
\hline \multirow[t]{2}{*}{ Agricultural } & 40 & -0.47 & -0.49 & -0.16 & -0.32 \\
\hline & & $(0.871)$ & $(0.772)$ & $(0.617)$ & $(0.524)$ \\
\hline \multirow[t]{2}{*}{ Energy and Govt. Tariffs } & 13 & 1.43 & 0.66 & 1.03 & 0.68 \\
\hline & & $(0.966)$ & $(0.929)$ & $(0.613)$ & $(0.530)$ \\
\hline \multirow[t]{2}{*}{ Overall Inflation } & 282 & $1.50^{\star \star \star}$ & $1.36^{\star \star \star}$ & $0.73^{\star \star *}$ & $0.69^{\star \star *}$ \\
\hline & & $(0.202)$ & $(0.197)$ & $(0.137)$ & $(0.126)$ \\
\hline
\end{tabular}

Sources: INEGI and authors' calculations.

Notes: Inflation is seasonally adjusted. Mean group estimation of the DID VAT effect per category: $\widehat{\varphi}=\frac{1}{N} \sum_{i} \widehat{\varphi}_{i}$, as in equation (III.1). The full report of the DID per category is available at the online repository. CS-Inflation: regression that includes weighted average cross-section inflation rate of the near cities defined in Section II. The estimates exclude subway

transportation, thus number of subclasses is 282. Standard errors in parentheses: $S E(\widehat{\varphi})=\sqrt{\frac{1}{N(N-1)} \sum_{i}\left(\widehat{\varphi}_{i}-\widehat{\varphi}\right)^{2}}$, and $\mathrm{p}$-values come from a t-distribution: ${ }^{\star} \mathrm{p}<0.10,{ }^{* \star} \mathrm{p}<0.05,{ }^{\star * \star} \mathrm{p}<0.01$.

Table 7. DID Bottom-Up Effect of VAT on Inflation by VAT-Regime

\begin{tabular}{|c|c|c|c|c|c|c|}
\hline & \multicolumn{3}{|c|}{ VAT 1995 (Apr) } & \multicolumn{3}{|c|}{ VAT 2014 (Jan) } \\
\hline & Count & Simple & CS-Inflation & Count & Simple & CS-Inflation \\
\hline \multirow[t]{2}{*}{ Zero-Rate } & 110 & 0.15 & -0.03 & 109 & 0.05 & 0.01 \\
\hline & & $(0.357)$ & $(0.329)$ & & $(0.245)$ & $(0.215)$ \\
\hline \multirow[t]{2}{*}{ Taxed } & 149 & $2.55^{\star \star *}$ & $2.47^{* * *}$ & 148 & $1.26^{\star * *}$ & $1.21^{\star * *}$ \\
\hline & & $(0.222)$ & $(0.229)$ & & $(0.156)$ & $(0.151)$ \\
\hline \multirow[t]{2}{*}{ Exempt } & 23 & $1.17^{\star \star}$ & $0.84^{*}$ & 25 & $0.61^{*}$ & $0.59^{*}$ \\
\hline & & $(0.486)$ & $(0.437)$ & & $(0.340)$ & $(0.327)$ \\
\hline
\end{tabular}

Sources: INEGI and authors' calculations.

Notes: Inflation is seasonally adjusted. Mean group estimation of the DID VAT effect per category: $\widehat{\varphi}=\frac{1}{N} \sum_{i} \widehat{\varphi}_{i}$, as in equation (III.1). The full report of the DID per category is available at the online repository. CS-Inflation: regression that includes weighted average cross-section inflation rate of the near cities defined in Section II. The estimates exclude subway transportation, thus number of subclasses is 282. In December of 1995 the Law changed medical and laboratory analysis from taxed to exempt; and in January of 2014 pet's food from zero-rate to taxed. Standard errors in parentheses: $S E(\widehat{\varphi})=\sqrt{\frac{1}{N(N-1)} \sum_{i}\left(\widehat{\varphi}_{i}-\widehat{\varphi}\right)^{2}}$, and $\mathrm{p}$-values come from a t-distribution: ${ }^{*} p<0.10,{ }^{\star *} p<0.05,{ }^{\star \star *} p<0.01$. 


\section{Distribution AND Welfare EFfects of The VAT REFORMS}

This section will present the welfare effect of the VAT reforms using Mexico's Household Survey of 2010. We estimate a non-linear demand system as Deaton and Muellbauer (1980) and Banks, Blundell, and Lewbel (1997) have proposed. Other studies have followed this method, see, for example, Heien and Wessells (1990), Abramovsky, Attanasio, and Phillips (2015), and Gaarder (2016). Once this system is estimated, it is easy to analyze the welfare implications using the before and after vector of prices. See for example King (1983), and Urzúa (2001) for the case of Mexico.

We use the pass-through estimations from the 1995 and 2014 VAT reforms shown in the previous Section III and impute those estimates into the 2010 prices to get the tax incidence. ${ }^{12}$ With the two sets of imputed prices and the system of demand functions, we proceed to estimate the welfare loss of the two reforms. Mexico's Statistics Agency (INEGI) use the 2010 Household Survey to calculate the weights on the CPI's base year. For that, they collect and aggregate each of the household's expenses and map them into each category of the CPI. We use the same correspondences to aggregate the households' expenditure up to 12 categories (see Section II for more detail).

\section{A. Estimation of a Quadratic Almost Ideal Demand System}

The Quadratic Almost Ideal Demand System (QUAIDS) is a general model that captures the non-linear term in the Engel's curves that the simple demand system of Deaton and Muellbauer (1980) does not. This non-linearity can be tested empirically and has valuable implication as Banks, Blundell, and Lewbel (1997) show.

On the other hand, household surveys usually have censoring problems reporting zero expenditure for some goods or services. A censor-correction aims to reduce the bias and inconsistency in the estimation. We extend the demand system and incorporate a bias-correcting term known as the inverse Mills ratio. We estimate the demand system using a two-step approach à la Heckman (1979) with independent probits and Non-linear Seemingly Unrelated Regressions (NLSUR). ${ }^{13}$ Tauchmann (2005) has proven how this approach is, in general, more efficient than most of the estimations available.

\footnotetext{
${ }^{12}$ The logical base for this calculation is provided in the Appendix B.

${ }^{13}$ See Heien and Wessells (1990) for a practical case where they estimate a censored demand system using a survey from the U.S. Department of Agriculture.
} 
The system of demand equations is the following:

$$
w_{i h}=\alpha_{i}+\sum_{j=1}^{n} \gamma_{i j} \ln p_{j}+\beta_{i} \ln \left(\frac{y_{h}}{a(\boldsymbol{p})}\right)+\frac{\lambda_{i}}{b(\boldsymbol{p})}\left[\ln \left(\frac{y_{h}}{a(\boldsymbol{p})}\right)\right]^{2}+\delta_{i} \widehat{R}_{i h}
$$

where $w_{i h}$ is the share of expenditure good $i$ in the household $h, \ln p_{j}$ is the logarithm of the price index for good $j, y_{h}$ is the total household expenditure, and $\widehat{R}_{i h}$ is the inverse Mills ratio estimated in the first stage with a probit model. ${ }^{14}$ The functions $\ln a(\boldsymbol{p})$ and $b(\boldsymbol{p})$ are, respectively, the price index and the Cobb-Douglas price aggregator:

$$
\begin{aligned}
\ln a(\boldsymbol{p}) & =\alpha_{0}+\sum_{i=1}^{n} \alpha_{i} \ln p_{i}+\frac{1}{2} \sum_{i=1}^{n} \sum_{j=1}^{n} \gamma_{i j} \ln p_{i} \ln p_{j} \\
b(\boldsymbol{p}) & =\prod_{i=1}^{n} p_{i}^{\beta_{i}}
\end{aligned}
$$

Finally, the following restrictions must be imposed to assure the system of equations (IV.1) represent demand functions consistent with the economic theory:

$$
\underbrace{\sum_{i}^{n} \alpha_{i}=1, \quad \sum_{i}^{n} \gamma_{i j}=0, \quad \sum_{i}^{n} \beta_{i}=0, \quad \sum_{i}^{n} \lambda_{i}=0}_{\text {adding-up }}, \underbrace{\sum_{j}^{n} \gamma_{i j}=0 \forall j}_{\text {homogeneity }}, \text { and } \underbrace{\gamma_{i j}=\gamma_{j i}}_{\text {Slutsky symmetry }} \text {. }
$$

The parameters in (IV.1) with restrictions (IV.2) are estimated by iterated feasible generalized nonlinear least-squares. One can exclude the $n$-th equation since it will be redundant given the restrictions stated in (IV.2).

Table 9 present the summary of the income and own-price estimated elasticities using the censored-augmented QUAIDS model. ${ }^{15}$ The numbers show that all the aggregates are normal goods as they have negative price elasticities. Food, beverages, tobacco, clothing, and footwear are necessary goods because the estimated income elasticity is less than one and the coefficient on the squared expenditure, $\lambda_{i}$, is negative - which gives concave-shaped Engel curves. Meanwhile, healthcare, transportation, and schooling have the highest price elasticities as these categories are likely to have close substitutes or a public-sector provider. Schooling, furniture, house supplies, recreation, and cultural activities, stand as a luxury with a large income elasticity and a steep convex Engel curve. The diverse goods' price-elasticity may seem odd, but this category

\footnotetext{
${ }^{14}$ To see the probit estimations and more detail on the specification go to Table 11 in the Appendix A.

${ }^{15}$ The complete set of estimates are in Table 12 and Table 13 in the Appendix A.
} 
includes housekeeping products, personal care, funerals, government fees, and other diverse goods that makes the variance across goods large.

These last estimations can provide some insight into the uniform rates discussion. For some studies, the VAT exemptions and zero-rates are a source of erosion. Dalsgaard (2000) and Huesca and Serrano (2005) estimate that the implicit subsidy of the zero-rate is between 1.6 to 1.8 of the GDP. Moreover, they argue that the zero-rate on food and other necessary goods is mostly capitalized by the top deciles as they get between 20 to 30 percent of the subsidy. According to these studies, the system would be more efficient under a uniform rate.

Our estimates show that the price-elasticities are relatively elastic and different from zero. This result is important for the goods that are exempt or under the zero-rate statute. Since the priceelasticity is not zero, if there were a positive VAT rate in these goods, the quantity exchanged in the market would go down, and the tax revenues would be lower than what the authors estimate. One could expect more efficiency from mixed VAT rates that are inversely proportional to the price elasticities of the goods (Diamond, 1975), while considering the complementarity of goods with leisure (Corlett and Hague, 1953). Not to mention that the VAT on food products could induce tax evasion with informal transactions; as Abramovsky, Attanasio, and Phillips (2015) show, approximately 47 percent of the expenditure on food, clothing, and footwear occur in informal establishments in Mexico.

Table 8. Expenditure Shares by Deciles (Percentage points)

\begin{tabular}{|c|c|c|c|c|c|c|c|c|c|c|c|}
\hline \multirow[b]{2}{*}{ Expenditure Category } & \multicolumn{10}{|c|}{ Deciles } & \multirow[b]{2}{*}{ Overal } \\
\hline & 1 & 2 & 3 & 4 & 5 & 6 & 7 & 8 & 9 & 10 & \\
\hline 1. Food and non-alcoholic beverages & 36.61 & 37.05 & 35.86 & 33.41 & 31.05 & 29.72 & 26.78 & 23.98 & 20.12 & 14.43 & 29.30 \\
\hline 2. Alcoholic beverages and tobacco & 0.41 & 0.48 & 0.43 & 0.44 & 0.51 & 0.39 & 0.47 & 0.42 & 0.45 & 0.41 & 0.44 \\
\hline 3. Clothing and footwear & 3.84 & 4.35 & 4.83 & 5.24 & 5.37 & 5.57 & 5.81 & 6.00 & 6.38 & 6.33 & 5.32 \\
\hline 4. Housing and utilities & 34.18 & 28.47 & 26.12 & 25.90 & 25.54 & 25.68 & 25.81 & 25.63 & 26.24 & 26.29 & 27.11 \\
\hline 5. Furniture and house supplies & 2.23 & 1.99 & 2.10 & 2.12 & 2.26 & 2.23 & 2.37 & 2.50 & 2.94 & 3.44 & 2.40 \\
\hline 6. Health care & 1.92 & 1.81 & 1.68 & 1.65 & 1.69 & 1.67 & 1.74 & 1.99 & 2.23 & 2.44 & 1.88 \\
\hline 7. Transportation & 4.70 & 5.96 & 6.81 & 7.39 & 7.82 & 8.01 & 8.31 & 8.61 & 8.52 & 8.67 & 7.40 \\
\hline 8. Communications & 1.54 & 2.16 & 2.75 & 3.19 & 3.72 & 4.14 & 4.73 & 5.32 & 6.03 & 7.87 & 4.04 \\
\hline 9. Recreation and cultural activities & 1.78 & 2.40 & 2.73 & 3.30 & 3.56 & 4.09 & 4.53 & 5.36 & 5.89 & 7.01 & 3.97 \\
\hline 10. Schooling & 1.99 & 2.87 & 3.49 & 3.83 & 4.63 & 4.86 & 5.32 & 5.77 & 6.40 & 7.55 & 4.57 \\
\hline 11. Restaurants and hotels & 2.50 & 3.66 & 4.31 & 4.87 & 5.35 & 5.60 & 6.23 & 6.88 & 7.54 & 9.45 & 5.53 \\
\hline 12. Diverse goods and services & 8.29 & 8.80 & 8.89 & 8.66 & 8.51 & 8.04 & 7.89 & 7.56 & 7.26 & 6.10 & 8.04 \\
\hline
\end{tabular}

Sources: INEGI, 2010 Household Survey (ENIGH) and authors' calculations.

Notes: Expenditure in the mapping bundle of the $283 \mathrm{CPI}$ goods and services for urban and rural households. 
Table 9. Estimated Income and Own-Price Elasticities

\begin{tabular}{lcccc}
\hline \hline \multicolumn{1}{c}{ Expenditure Category } & $\begin{array}{c}\text { Percent of } \\
\text { Expenditure }\end{array}$ & $\begin{array}{c}\text { Income } \\
\text { Elasticities }\end{array}$ & $\begin{array}{c}\text { Own-Price Elasticities } \\
\text { (Compensated) }\end{array}$ & $\begin{array}{c}\text { Own-Price Elasticities } \\
\text { (Uncompensated) }\end{array}$ \\
\hline 1. Food and non-alcoholic beverages & 29.30 & 0.14 & -0.86 & -0.95 \\
2. Alcoholic beverages and tobacco & 0.44 & 0.73 & -0.91 & -0.94 \\
3. Clothing and footwear & 5.32 & 0.94 & -0.93 & -1.00 \\
4. Housing and utilities & 27.11 & 1.17 & -0.84 & -1.05 \\
5. Furniture and house supplies & 2.40 & 2.06 & -1.00 & -1.04 \\
6. Health care & 1.88 & 1.96 & -74.77 & -74.80 \\
7. Transportation & 7.40 & 1.31 & -1.39 & -1.48 \\
8. Communications & 4.04 & 1.31 & -0.97 & -1.03 \\
9. Recreation and cultural activities & 3.97 & 1.66 & -0.43 & -0.51 \\
10. Schooling & 4.57 & 2.24 & -1.10 & -1.23 \\
11. Restaurants and hotels & 5.53 & 1.32 & -0.94 & -1.04 \\
12. Diverse goods and services & 8.04 & 1.18 & -159.37 & -159.43 \\
\hline \hline
\end{tabular}

Sources: INEGI, 2010 Household Survey (ENIGH) and authors' calculations.

Notes: Estimates come from a Quadratic Almost Ideal Demand System (QUAIDS) using a Non-linear system of Seemingly Unrelated Regressions (NLSUR) with data from the household survey and the $\mathrm{CPI}$ aggregated at 12 categories of expenditure.

\section{B. The Measurement of Welfare Loss}

To analyze the welfare loss we introduce a measure of equivalent variation. We define the equivalent expenditure as the amount of money that allows a household to get the same utility level as before the VAT reforms. ${ }^{16}$ Given the change in prices, the equivalent expenditure is the amount of money that allows the household to reach a level of expenditure as good as the one they had before the reforms. The higher the equivalent expenditure is to the original expenditure, the higher is the welfare loss.

Formally, we define the household's $h$ change in welfare as follows:

$$
\Delta \text { Welfare }_{h}=e\left(\boldsymbol{p}, V\left(\boldsymbol{p}, y_{h}\right)\right)-e\left(\tilde{\boldsymbol{p}}, V\left(\boldsymbol{p}, y_{h}\right)\right)=y_{h}-\tilde{y}_{h} .
$$

Where $e(\cdot)$ is the expenditure function and $V(\cdot)$ is the value function. ${ }^{17} \boldsymbol{p}$ is the vector of actual prices and $\tilde{\boldsymbol{p}}$ is the imputed price vector from the VAT reforms using our estimates on Section III. ${ }^{18}$ Finally, $y_{h}$ is the original expenditure and $\tilde{y}_{h}$ is the equivalent expenditure, which after some algebra one can show it to be:

\footnotetext{
${ }^{16}$ See for example the definition of equivalent income in King (1983) and the references therein.

${ }^{17}$ The value function is given by $\ln V\left(\boldsymbol{p}, y_{h}\right)=\left[\left(\frac{\ln y_{h}-\ln a(\boldsymbol{p})}{b(\boldsymbol{p})}\right)^{-1}+\lambda(\boldsymbol{p})\right]^{-1}$, with $\lambda(\boldsymbol{p})=\sum_{i=1}^{n} \lambda_{i} \ln p_{i}$. See Banks, Blundell, and Lewbel (1997) for the proofs and derivation of the value function to the demand system.

${ }^{18}$ We use the coefficients $\varphi$ that are statistically significant at 10 percent and a zero effect otherwise.
} 


$$
\tilde{y}_{h}=\ln a(\tilde{\boldsymbol{p}})+\frac{b(\tilde{\boldsymbol{p}})\left[\ln y_{h}-\ln a(\boldsymbol{p})\right]}{b(\boldsymbol{p})+\left[\ln y_{h}-\ln a(\boldsymbol{p})\right] \cdot[\lambda(\boldsymbol{p})-\lambda(\tilde{\boldsymbol{p}})]} .
$$

Overall, we estimate that the average household lost 1.4 percent of its monthly expenditure from the 1995 reform and 0.7 from 2014. That makes a 0.27 and 0.15 percent loss of monthly expenditure for a one percent increase in the VAT rate respectively. The welfare loss from the 1995 VAT reform is higher than the 2014 reform because, as we discussed in the previous section, inflation was a higher and more persistent process, so shocks used to have a larger impact and a longer life in 1995 than in 2014.

We find that the welfare loss is progressive in absolute and relative terms. Table 10 shows the overall welfare loss and the breakdown by decile of monetary income. Normalizing the figures to a one percent increase in the VAT rate, the households in the 10th decile loss on average 0.28 percent of its total expenditure in 1995 and 0.16 percent in 2014. Meanwhile, the households in the lowest decile loss 0.26 and 0.13 percent (Figure 5).

Two reasons explain most of the progressive effect of the VAT on the households. First, the VAT is not uniform for all goods: low-income households tend to spend a higher share of their incomes in untaxed goods, like food and non-alcoholic beverages (Table 8). Second, the tax incidence on prices is quite heterogeneous as we showed earlier on Section III. The most affected prices from the reforms were communications, healthcare, and schooling, which are more intensively consumed by the high-income households. Therefore, high-income households will be relatively more taxed than the low-income households. These expenditure patterns are also consistent with the income-elasticities of the demand system previously estimated (Table 9).

We also identify a source of regressivity in the diverse goods and services. This regressivity happens because most of its components are taxed with the VAT, and the low-income households spend an important share on them (Table 8). These types of goods include housekeeping products, personal care, funerals, and government fees. 
Table 10. Distribution of Welfare Loss by Deciles

\begin{tabular}{|c|c|c|c|c|c|}
\hline \multirow[b]{2}{*}{ Decile } & \multicolumn{3}{|c|}{ Monthly average per household (MX\$2010) } & \multicolumn{2}{|c|}{ Percent of original expenditure } \\
\hline & $\begin{array}{c}\text { Original } \\
\text { Expenditure }\end{array}$ & $\begin{array}{c}\text { Welfare Loss } \\
\text { VAT } 1995 \\
\end{array}$ & $\begin{array}{c}\text { Welfare Loss } \\
\text { VAT } 2014 \\
\end{array}$ & $\begin{array}{c}\text { Welfare Loss } \\
\text { VAT } 1995 \\
\end{array}$ & $\begin{array}{c}\text { Welfare Loss } \\
\text { VAT } 2014\end{array}$ \\
\hline 1 & $3,071.1$ & -39.21 & -19.49 & -1.28 & -0.63 \\
\hline 2 & $3,966.4$ & -51.17 & -25.87 & -1.29 & -0.65 \\
\hline 3 & $4,587.0$ & -59.22 & -29.92 & -1.29 & -0.65 \\
\hline 4 & $5,454.9$ & -71.20 & -36.65 & -1.31 & -0.67 \\
\hline 5 & $6,365.5$ & -83.73 & -43.66 & -1.32 & -0.69 \\
\hline 6 & $7,246.0$ & -95.69 & -50.21 & -1.32 & -0.69 \\
\hline 7 & $8,531.9$ & -113.33 & -60.04 & -1.33 & -0.70 \\
\hline 8 & $10,284.3$ & -137.54 & -73.67 & -1.34 & -0.72 \\
\hline 9 & $13,522.8$ & -184.03 & -101.51 & -1.36 & -0.75 \\
\hline 10 & $24,323.2$ & -340.01 & -196.04 & -1.40 & -0.81 \\
\hline Overall & $8,733.1$ & -117.48 & -63.69 & -1.35 & -0.73 \\
\hline
\end{tabular}

Sources: INEGI, 2010 Household Survey (ENIGH) and authors' calculations.

Notes: Estimates come from a Quadratic Almost Ideal Demand System (QUAIDS) using a Non-linear system of Seemingly Unrelated Regressions (NLSUR) with data from the household survey and the CPI aggregated at 12 categories of expenditure. The welfare loss is the compensating variation, calculated with equation (IV.3). The household deciles are calculated using the monetary income in the Survey (ENIGH).

Figure 5. Distribution of Welfare Loss by Deciles In Percent of Original Expenditure

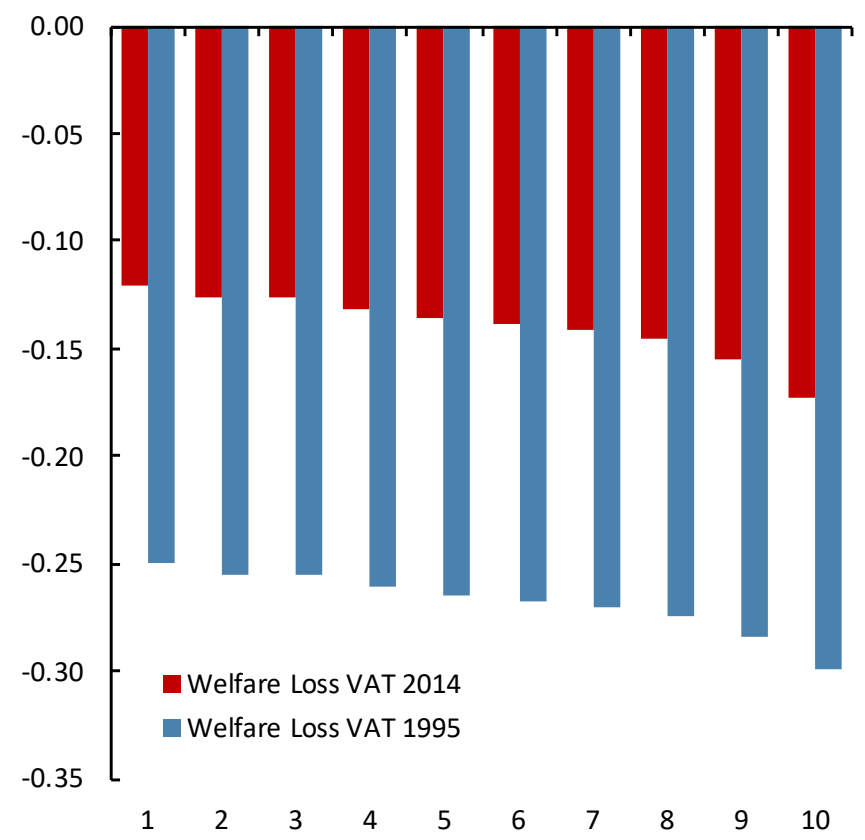

Sources: INEGI, 2010 Household Survey (ENIGH) and authors' calculations.

Notes: Estimates come from Table 10 but loss is normalized to a 1 percent VAT increase. 


\section{Conclusions}

This study shows the effect on prices of Mexico's VAT reforms of April of 1995 and of January of 2014 and their impact on households' welfare. The highest effect on prices and the worst effect on welfare came from the five-percentage-point increase in the general VAT rate that took place in 1995. We show that a one percentage point increase in the VAT rate translates into a 0.4 percentage point growth in prices (40 percent pass-through) and a 0.27 percent loss of monthly expenditure for the average household. Then, in 2014, the VAT effect dropped to a 0.14 percentage point growth in prices and a 0.15 percent loss of monthly expenditure for the average household.

The taxed goods carry the highest burden with a fifty percent pass-through from the VAT hike in 1995, and less than half of that pass-through for the VAT reform of 2014. Although the zero-rate goods do not show any significance, the exempt goods do show significant effects up to 12 percent in 2014, coming from a 17 percent pass-through in 1995.

The population benefits from a low inflation regime as it dampens the overall effect of the changes in the VAT rate to inflation and reduces the welfare loss. However, we show that the VAT rate has asymmetric effects between cities with a lower incidence on the northern cities.

The reduction of the VAT effect on inflation from 1995 to 2014 regarding its composition was mainly driven by merchandise such as beverages, clothing, and furniture. Meanwhile, the effect on some services soared (e.g., communications, education, and healthcare). Overall the household's loss was less in 2014 because the components that decrease more than compensate for the ones that increased. Since the effect on prices was limited, we conclude that the burden of the VAT tax was indeed shared between producers and consumers.

From a policy perspective, we present evidence that the Engel curves are non-linear, and that

price-elasticities are not perfectly inelastic. This fact is relevant to the discussion of uniform VAT rates because one could overestimate the potential revenue that would be collected if all the exemptions were removed. 


\section{REFERENCES}

Abramovsky, Laura, Orazio Attanasio, and David Phillips, 2015, "Value Added Tax Policy and The Case for Uniformity: Empirical Evidence from Mexico," IFS Working Papers W15/08, Institute for Fiscal Studies.

Aportela, Fernando, and Alejandro Werner, 2002, "La Reforma al Impuesto al Valor Agregado de 1995: Efecto Inflacionario, Incidencia y Elasticidades Relativas," Documento de Investigación 2002-01, Banco de México.

Ashenfelter, Orley, and David Card, 1985, "Using the Longitudinal Structure of Earnings to Estimate the Effect of Training Programs," The Review of Economics and Statistics, Vol. 67, No. 4, pp. 648-660.

Banks, James, Richard Blundell, and Arthur Lewbel, 1997, "Quadratic Engel Curves and Consumer Demand," The Review of Economics and Statistics, Vol. 79, No. 4, pp. 527-539.

Banzarti, Youssef, and Dorian Carloni, 2017, "Who Really Benefits from Consumption Tax Cuts? Evidence from a Large VAT Reform in France," NBER Working Paper 23848, NBER.

Benedek, Dora, Ruud De Mooij, Michael Keen, and Philippe Wingender, 2015, "Estimating VAT Pass-Through," IMF Working Paper, Vol. 214.

Bird, Richard M., and Pierre-Pascal Gendron, 2007, The VAT in Developing and Transitional Countries (Cambridge University Press).

Carare, Alina, and Stephan Danninger, 2008, "Inflation Smoothing and the Modest Effect of VAT in Germany," IMF Working Paper, Vol. 175.

Card, David, and Alan B. Krueger, 1994, "Minimum Wages and Employment: A Case Study of the Fast-Food Industry in New Jersey and Pennsylvania," The American Economic Review, Vol. 84, No. 4, pp. 772-793.

Chiquiar, Daniel, Antonio E. Noriega, and Manuel Ramos-Francia, 2010, "A Time Series Approach to Test a Change in Inflation Persistence: The Mexican Experience," Applied Economics, Vol. 42, No. 24, pp. 3067-3075.

Corlett, W. J., and D. C. Hague, 1953, "Complementarity and the Excess Burden of Taxation," The Review of Economic Studies, Vol. 21, No. 1, pp. 21-30.

Dalsgaard, Thomas, 2000, "The Tax System in Mexico: A Need for Strengthening the RevenueRaising Capacity," Economics Department Working Papers 233, OECD.

Deaton, Angus, and John Muellbauer, 1980, “An Almost Ideal Demand System," American Economic Review, Vol. 70, No. 3, pp. 312-326.

Diamond, Peter A., 1975, “A Many-person Ramsey Tax Rule,” Journal of Public Economics, Vol. 4, No. 4, pp. 335-342.

Gaarder, Ingvil, 2016, "Incidence and Distributional Effects of Value Added Taxes," Working Paper, available at SSRN: https://ssrn.com/abstract=2784559. 
Heckman, James J., 1979, "Sample Selection Bias as a Specification Error," Econometrica, Vol. 47, No. 1, pp. 153-161.

Heien, Dale, and Cathy Roheim Wessells, 1990, "Demand Systems Estimation with Microdata: A Censored Regression Approach," Journal of Business \& Economic Statistics, Vol. 8, No. 3, pp. 365-371.

Huesca, Luis, and Alfredo Serrano, 2005, "El Impacto Fiscal Redistributivo Desagregado del Impuesto al Valor Agregado en México: Vías de Reforma," Investigación Económica, Vol. LXIV, No. 253, pp. 89-112.

INEGI, 2011, “Encuesta Nacional de Ingresos y Gastos de los Hogares 2010: ENIGH,” Descripción de la base de datos, Instituto Nacional de Estadística y Geografía.

King, Mervyn A., 1983, "Welfare analysis of tax reforms using household data," Journal of Public Economics, Vol. 21, No. 2, pp. 183-214.

Kosonen, Tuomas, 2015, "More and cheaper haircuts after VAT cut? On the efficiency and incidence of service sector consumption taxes," Journal of Public Economics, Vol. 131, pp. $87-100$.

Mariscal, Rodrigo, Andrew Powell, and Pilar Tavella, 2018, "On the Credibility of InflationTargeting Regimes in Latin America," Economia: Brookings Institution Press, Vol. 18, No. 2, pp. 1-24.

Pesaran, M. Hashem, 2004, "General Diagnostic Tests for Cross Section Dependence in Panels," Cambridge Working Papers in Economics, Vol. June 2004, No. 0435.

Politi, Ricardo Batista, and Enlinson Mattos, 2011, "Ad-Valorem Tax Incidence and After-Tax Price Adjustments: Evidence from Brazilian Basic Basket Food," Canadian Journal of Economics, Vol. 44, No. 4, pp. 1438-1470.

Schmidt-Hebbel, Klaus, and Alejandro Werner, 2002, "Inflation Targeting in Brazil, Chile, and Mexico: Performance, Credibility, and the Exchange Rate," Working Paper No. 171, July 2002, Central Bank of Chile.

Tauchmann, Harald, 2005, "Efficiency of Two-step Estimators for Censored Systems of Equations: Shonkwiler and Yen Reconsidered," Applied Economics, Vol. 37, No. 4, pp. 367-374.

Urzúa, Carlos M., 2001, "Welfare Consequences of a Recent Tax Reform in Mexico," Estudios Económicos, Vol. 16, No. 1, pp. 57-72. 
Appendix A. Regression Results

\section{Appendix Table 1. DID on Inflation for the VAT Reform of 1995}

\begin{tabular}{|c|c|c|c|c|c|c|c|c|c|c|c|c|}
\hline & \multicolumn{12}{|c|}{ Dependent variable: } \\
\hline & \multicolumn{6}{|c|}{ Monthly Inflation (NSA) } & \multicolumn{6}{|c|}{ Monthly Inflation } \\
\hline & $(1)$ & (2) & (3) & (4) & (5) & (6) & (7) & (8) & (9) & $(10)$ & $(11)$ & $(12)$ \\
\hline Non-Border city & $\begin{array}{c}-0.784^{* *} \\
(0.303)\end{array}$ & $\begin{array}{l}-0.264 \\
(0.368)\end{array}$ & $\begin{array}{l}-0.264 \\
(0.335)\end{array}$ & $\begin{array}{c}-0.264 \\
(0.339)\end{array}$ & $\begin{array}{l}-0.167 \\
(0.162)\end{array}$ & $\begin{array}{l}-0.164 \\
(0.179)\end{array}$ & $\begin{array}{c}-1.172^{* * *} \\
(0.303)\end{array}$ & $\begin{array}{l}-0.190 \\
(0.324)\end{array}$ & $\begin{array}{l}-0.190 \\
(0.338)\end{array}$ & $\begin{array}{l}-0.190 \\
(0.345)\end{array}$ & $\begin{array}{l}-0.310 \\
(0.261)\end{array}$ & $\begin{array}{c}-0.343 \\
(0.296)\end{array}$ \\
\hline VAT 1995 (Mar) & $\begin{array}{c}0.840^{* * *} \\
(0.285)\end{array}$ & & & & $\begin{array}{c}3.329^{* * *} \\
(0.310)\end{array}$ & $\begin{array}{c}0.122 \\
(0.345)\end{array}$ & $\begin{array}{c}0.472 \\
(0.285)\end{array}$ & & & & $\begin{array}{c}3.131^{* * *} \\
(0.351)\end{array}$ & $\begin{array}{c}0.138 \\
(0.399)\end{array}$ \\
\hline Non-Border city * VAT 1995 (Mar) & $\begin{array}{l}0.519^{*} \\
(0.310)\end{array}$ & & & & $\begin{array}{l}-0.097 \\
(0.342)\end{array}$ & $\begin{array}{l}-0.152 \\
(0.333)\end{array}$ & $\begin{array}{c}0.982^{* * *} \\
(0.310)\end{array}$ & & & & $\begin{array}{l}0.120 \\
(0.391)\end{array}$ & $\begin{array}{c}0.150 \\
(0.432)\end{array}$ \\
\hline VAT 1995 (Apr) & & $\begin{array}{c}0.867^{* *} \\
(0.384)\end{array}$ & & & $\begin{array}{c}4.196^{* * *} \\
(0.134)\end{array}$ & $\begin{array}{c}-1.109^{* * *} \\
(0.419)\end{array}$ & & $\begin{array}{c}0.672^{* *} \\
(0.329)\end{array}$ & & & $\begin{array}{c}3.803^{* * *} \\
(0.331)\end{array}$ & $\begin{array}{c}-1.126^{* *} \\
(0.539)\end{array}$ \\
\hline Non-Border city * VAT 1995 (Apr) & & $\begin{array}{c}1.534^{* * *} \\
(0.409)\end{array}$ & & & $\begin{array}{c}1.436^{* * *} \\
(0.199)\end{array}$ & $\begin{array}{c}1.218^{* * *} \\
(0.207)\end{array}$ & & $\begin{array}{c}1.768^{* * *} \\
(0.365)\end{array}$ & & & $\begin{array}{c}1.888^{* * * *} \\
(0.369)\end{array}$ & $\begin{array}{c}1.987^{* * *} \\
(0.413)\end{array}$ \\
\hline VAT 1995 (May) & & & $\begin{array}{c}-2.136^{* * *} \\
(0.402)\end{array}$ & & $\begin{array}{c}1.192^{* * *} \\
(0.223)\end{array}$ & $\begin{array}{c}-0.484^{*} \\
(0.247)\end{array}$ & & & $\begin{array}{c}-1.706^{* * *} \\
(0.491)\end{array}$ & & $\begin{array}{c}1.425^{* * *} \\
(0.221)\end{array}$ & $\begin{array}{l}-0.393 \\
(0.312)\end{array}$ \\
\hline Non-Border city * VAT 1995 (May) & & & $\begin{array}{l}0.734^{*} \\
(0.418)\end{array}$ & & $\begin{array}{c}0.637^{* * *} \\
(0.236)\end{array}$ & $\begin{array}{l}0.537^{* *} \\
(0.239)\end{array}$ & & & $\begin{array}{c}0.516 \\
(0.501)\end{array}$ & & $\begin{array}{c}0.636^{* * * *} \\
(0.240)\end{array}$ & $\begin{array}{c}0.688^{* * * *} \\
(0.263)\end{array}$ \\
\hline VAT 1995 (Jun) & & & & $\begin{array}{c}-2.848^{* * *} \\
(0.353)\end{array}$ & $\begin{array}{c}0.481^{* * *} \\
(0.157)\end{array}$ & $\begin{array}{c}-0.330^{*} \\
(0.169)\end{array}$ & & & & $\begin{array}{c}-2.671^{* * *} \\
(0.374)\end{array}$ & $\begin{array}{c}0.460 \\
(0.282)\end{array}$ & $\begin{array}{l}-0.513 \\
(0.321)\end{array}$ \\
\hline Non-Border city * VAT 1995 (Jun) & & & & $\begin{array}{c}0.525 \\
(0.387)\end{array}$ & $\begin{array}{l}0.427^{* *} \\
(0.172)\end{array}$ & $\begin{array}{l}0.376^{* *} \\
(0.189)\end{array}$ & & & & $\begin{array}{c}0.562 \\
(0.405)\end{array}$ & $\begin{array}{l}0.682^{* *} \\
(0.302)\end{array}$ & $\begin{array}{l}0.734^{* *} \\
(0.354)\end{array}$ \\
\hline Cross-section Inflation (NSA) & & & & & & $\begin{array}{c}0.991^{* * *} \\
(0.075)\end{array}$ & & & & & & \\
\hline Cross-section Inflation & & & & & & & & & & & & $\begin{array}{c}0.914^{* * *} \\
(0.093)\end{array}$ \\
\hline Constant & $\begin{array}{c}4.875^{* * *} \\
(0.289)\end{array}$ & $\begin{array}{c}5.715^{* * *} \\
(0.348)\end{array}$ & $\begin{array}{c}5.715^{* * *} \\
(0.316)\end{array}$ & $\begin{array}{c}5.715^{* * *} \\
(0.307)\end{array}$ & $\begin{array}{c}2.386^{* * *} \\
(0.141)\end{array}$ & $\begin{array}{c}0.156 \\
(0.249)\end{array}$ & $\begin{array}{c}5.185^{* * *} \\
(0.289)\end{array}$ & $\begin{array}{c}5.657^{* * *} \\
(0.292)\end{array}$ & $\begin{array}{c}5.657^{* * *} \\
(0.314)\end{array}$ & $\begin{array}{c}5.657^{* * *} \\
(0.313)\end{array}$ & $\begin{array}{c}2.526^{* * *} \\
(0.245)\end{array}$ & $\begin{array}{c}0.464 \\
(0.401)\end{array}$ \\
\hline
\end{tabular}

Sources: INEGI and authors' calculations.

Notes: Average cross-section inflation is a weighted average cross-section inflation rate of the near cities defined in Section II. The weights are calculated using the inverse of the Euclidean distance between cities and the own city weight (inverse distance) is set to zero. Block-bootstrap standard errors in parentheses (bootstrap by city with 500 repetitions), ${ }^{*} p<0.10,{ }^{* *} p<0.05,{ }^{* \star *} p<0.01$. 
Appendix Table 2. DID on Inflation for the VAT Reform of 2014

\begin{tabular}{|c|c|c|c|c|c|c|c|c|c|c|}
\hline & \multicolumn{10}{|c|}{ Dependent variable: } \\
\hline & \multicolumn{5}{|c|}{ Monthly Inflation (NSA) } & \multicolumn{5}{|c|}{ Monthly Inflation } \\
\hline & $(1)$ & $(2)$ & $(3)$ & $(4)$ & $(5)$ & $(6)$ & $(7)$ & $(8)$ & (9) & $(10)$ \\
\hline Border city & $\begin{array}{c}1.294 \\
(1.124)\end{array}$ & $\begin{array}{c}-0.054 \\
(0.106)\end{array}$ & $\begin{array}{c}-0.054 \\
(0.096)\end{array}$ & $\begin{array}{l}-0.001 \\
(0.035)\end{array}$ & $\begin{array}{c}-0.002 \\
(0.035)\end{array}$ & $\begin{array}{c}-0.084 \\
(0.081)\end{array}$ & $\begin{array}{c}0.012 \\
(0.094)\end{array}$ & $\begin{array}{c}0.012 \\
(0.094)\end{array}$ & $\begin{array}{c}-0.014 \\
(0.034)\end{array}$ & $\begin{array}{r}-0.014 \\
(0.032)\end{array}$ \\
\hline VAT 2013 (Dec) & $\begin{array}{l}-0.509 \\
(0.337)\end{array}$ & & & $\begin{array}{c}0.246^{* * *} \\
(0.053)\end{array}$ & $\begin{array}{c}-0.132 \\
(0.127)\end{array}$ & $\begin{array}{c}-0.135^{* * *} \\
(0.041)\end{array}$ & & & $\begin{array}{c}0.048 \\
(0.035)\end{array}$ & $\begin{array}{r}-0.001 \\
(0.035)\end{array}$ \\
\hline Border city * VAT 2013 (Dec) & $\begin{array}{c}-1.348 \\
(1.120)\end{array}$ & & & $\begin{array}{c}-0.053 \\
(0.125)\end{array}$ & $\begin{array}{c}0.022 \\
(0.144)\end{array}$ & $\begin{array}{c}0.096 \\
(0.138)\end{array}$ & & & $\begin{array}{c}0.026 \\
(0.119)\end{array}$ & $\begin{array}{c}0.027 \\
(0.118)\end{array}$ \\
\hline VAT 2014 (Jan) & & $\begin{array}{c}0.347^{* * *} \\
(0.095)\end{array}$ & & $\begin{array}{c}0.593^{* * *} \\
(0.060)\end{array}$ & $\begin{array}{c}-0.345 \\
(0.298)\end{array}$ & & $\begin{array}{c}0.239^{* * *} \\
(0.070)\end{array}$ & & $\begin{array}{c}0.287^{* * *} \\
(0.049)\end{array}$ & $\begin{array}{c}-0.063 \\
(0.078)\end{array}$ \\
\hline Border city * VAT 2014 (Jan) & & $\begin{array}{c}1.005^{* * *} \\
(0.238)\end{array}$ & & $\begin{array}{c}0.952^{* * *} \\
(0.154)\end{array}$ & $\begin{array}{c}0.787^{* * *} \\
(0.171)\end{array}$ & & $\begin{array}{c}0.696^{* *} \\
(0.315)\end{array}$ & & $\begin{array}{c}0.722^{* * *} \\
(0.275)\end{array}$ & $\begin{array}{c}0.744^{* *} \\
(0.308)\end{array}$ \\
\hline VAT 2014 (Feb) & & & $\begin{array}{c}-0.253^{* * *} \\
(0.067)\end{array}$ & $\begin{array}{l}-0.007 \\
(0.040)\end{array}$ & $\begin{array}{c}0.018 \\
(0.040)\end{array}$ & & & $\begin{array}{c}-0.134^{* * *} \\
(0.045)\end{array}$ & $\begin{array}{c}-0.086^{* *} \\
(0.034)\end{array}$ & $\begin{array}{r}-0.021 \\
(0.034)\end{array}$ \\
\hline Border city * VAT 2014 (Feb) & & & $\begin{array}{c}-0.085 \\
(0.164)\end{array}$ & $\begin{array}{l}-0.137 \\
(0.147)\end{array}$ & $\begin{array}{c}-0.146 \\
(0.141)\end{array}$ & & & $\begin{array}{c}-0.035 \\
(0.119)\end{array}$ & $\begin{array}{c}-0.008 \\
(0.064)\end{array}$ & $\begin{array}{c}-0.014 \\
(0.060)\end{array}$ \\
\hline Cross-section Inflation (NSA) & & & & & $\begin{array}{c}1.422^{* * *} \\
(0.427)\end{array}$ & & & & & \\
\hline Cross-section Inflation & & & & & & & & & & $\begin{array}{c}0.804^{* * *} \\
(0.106)\end{array}$ \\
\hline Constant & $\begin{array}{c}0.979^{* * *} \\
(0.320)\end{array}$ & $\begin{array}{c}0.470^{* * *} \\
(0.048)\end{array}$ & $\begin{array}{c}0.470^{* * *} \\
(0.050)\end{array}$ & $\begin{array}{c}0.225^{* * *} \\
(0.008)\end{array}$ & $\begin{array}{c}-0.093 \\
(0.095)\end{array}$ & $\begin{array}{c}0.454^{* * *} \\
(0.036)\end{array}$ & $\begin{array}{c}0.318^{* * *} \\
(0.037)\end{array}$ & $\begin{array}{c}0.318^{* * *} \\
(0.036)\end{array}$ & $\begin{array}{c}0.270^{* * *} \\
(0.008)\end{array}$ & $\begin{array}{c}0.058^{* *} \\
(0.030)\end{array}$ \\
\hline
\end{tabular}

Sources: INEGI and authors' calculations.

Notes: Average cross-section inflation is a weighted average cross-section inflation rate of the near cities defined in Section II. The weights are calculated using the inverse of the Euclidean distance between cities and the own city weight (inverse distance) is set to zero. Block-bootstrap standard errors in parentheses (bootstrap by city with 500 repetitions), ${ }^{*} p<0.10,{ }^{*} p<0.05,{ }^{\star \star *} p<0.01$. 
Appendix Table 3. DID on Inflation for the VAT Reform of 1991

\begin{tabular}{|c|c|c|c|c|c|c|c|c|c|c|}
\hline & \multicolumn{10}{|c|}{ Dependent variable: } \\
\hline & \multicolumn{5}{|c|}{ Monthly Inflation (NSA) } & \multicolumn{5}{|c|}{ Monthly Inflation } \\
\hline & $(1)$ & $(2)$ & $(3)$ & $(4)$ & $(5)$ & $(6)$ & $(7)$ & $(8)$ & $(9)$ & $(10)$ \\
\hline Border city & $\begin{array}{c}-0.150 \\
(0.150)\end{array}$ & $\begin{array}{l}-0.081 \\
(0.155)\end{array}$ & $\begin{array}{r}-0.081 \\
(0.148)\end{array}$ & $\begin{array}{c}-0.019 \\
(0.057)\end{array}$ & $\begin{array}{c}0.001 \\
(0.042)\end{array}$ & $\begin{array}{c}-0.192 \\
(0.128)\end{array}$ & $\begin{array}{c}-0.234 \\
(0.179)\end{array}$ & $\begin{array}{c}-0.234 \\
(0.171)\end{array}$ & $\begin{array}{l}-0.021 \\
(0.053)\end{array}$ & $\begin{array}{c}0.001 \\
(0.061)\end{array}$ \\
\hline VAT 1991 (Nov) & $\begin{array}{c}0.945^{* * *} \\
(0.099)\end{array}$ & & & $\begin{array}{c}1.205^{* * *} \\
(0.114)\end{array}$ & $\begin{array}{l}0.0005 \\
(0.159)\end{array}$ & $\begin{array}{c}0.447^{* * *} \\
(0.130)\end{array}$ & & & $\begin{array}{c}0.663^{* * *} \\
(0.099)\end{array}$ & $\begin{array}{c}0.004 \\
(0.168)\end{array}$ \\
\hline Border city * VAT 1991 (Nov) & $\begin{array}{c}0.069 \\
(0.211)\end{array}$ & & & $\begin{array}{c}-0.062 \\
(0.159)\end{array}$ & $\begin{array}{c}0.091 \\
(0.154)\end{array}$ & $\begin{array}{c}-0.042 \\
(0.187)\end{array}$ & & & $\begin{array}{l}-0.213 \\
(0.153)\end{array}$ & $\begin{array}{l}-0.154 \\
(0.186)\end{array}$ \\
\hline VAT 1991 (Dec) & & $\begin{array}{l}-0.038 \\
(0.073)\end{array}$ & & $\begin{array}{c}1.166^{* * *} \\
(0.082)\end{array}$ & $\begin{array}{c}0.032 \\
(0.136)\end{array}$ & & $\begin{array}{c}-0.397^{* * *} \\
(0.085)\end{array}$ & & $\begin{array}{c}0.266^{* * *} \\
(0.079)\end{array}$ & $\begin{array}{c}0.033 \\
(0.099)\end{array}$ \\
\hline Border city * VAT 1991 (Dec) & & $\begin{array}{l}-0.014 \\
(0.298)\end{array}$ & & $\begin{array}{c}-0.076 \\
(0.211)\end{array}$ & $\begin{array}{l}-0.110 \\
(0.186)\end{array}$ & & $\begin{array}{c}0.146 \\
(0.091)\end{array}$ & & $\begin{array}{l}-0.067 \\
(0.164)\end{array}$ & $\begin{array}{c}-0.106 \\
(0.169)\end{array}$ \\
\hline VAT 1992 (Jan) & & & $\begin{array}{c}-0.463^{* * *} \\
(0.094)\end{array}$ & $\begin{array}{c}0.742^{* * *} \\
(0.052)\end{array}$ & $\begin{array}{c}0.049 \\
(0.095)\end{array}$ & & & $\begin{array}{c}-0.663^{* * *} \\
(0.093)\end{array}$ & $\begin{array}{l}0.0004 \\
(0.051)\end{array}$ & $\begin{array}{c}0.024 \\
(0.061)\end{array}$ \\
\hline Border city * VAT 1992 (Jan) & & & $\begin{array}{c}0.025 \\
(0.192)\end{array}$ & $\begin{array}{c}-0.037 \\
(0.145)\end{array}$ & $\begin{array}{c}-0.088 \\
(0.117)\end{array}$ & & & $\begin{array}{c}0.257^{* *} \\
(0.120)\end{array}$ & $\begin{array}{c}0.043 \\
(0.078)\end{array}$ & $\begin{array}{c}0.049 \\
(0.083)\end{array}$ \\
\hline Cross-section Inflation (NSA) & & & & & $\begin{array}{c}0.973^{* * *} \\
(0.088)\end{array}$ & & & & & \\
\hline Cross-section Inflation & & & & & & & & & & $\begin{array}{c}0.955^{* * *} \\
(0.100)\end{array}$ \\
\hline Constant & $\begin{array}{c}1.204^{* * *} \\
(0.056)\end{array}$ & $\begin{array}{c}2.148^{* * *} \\
(0.109)\end{array}$ & $\begin{array}{c}2.148^{* * *} \\
(0.094)\end{array}$ & $\begin{array}{c}0.943^{* * *} \\
(0.016)\end{array}$ & $\begin{array}{c}0.025 \\
(0.080)\end{array}$ & $\begin{array}{c}1.339^{* * *} \\
(0.054)\end{array}$ & $\begin{array}{c}1.787^{* * *} \\
(0.099)\end{array}$ & $\begin{array}{c}1.787^{* * *} \\
(0.100)\end{array}$ & $\begin{array}{c}1.123^{* * *} \\
(0.013)\end{array}$ & $\begin{array}{c}0.049 \\
(0.105) \\
\end{array}$ \\
\hline
\end{tabular}

Sources: INEGI and authors' calculations.
Notes: Average cross-section inflation is a weighted average cross-section inflation rate of the near cities defined in Section II. The weights are calculated using the inverse of the Euclidean distance between cities and the own city weight (inverse distance) is set to zero. Block-bootstrap standard errors in parentheses (bootstrap by city with 500 repetitions), ${ }^{*} p<0.10,{ }^{* *} p<0.05,{ }^{* *} p<0.01$. 
Appendix Table 4. DID on Inflation for the VAT Reform of 2010

\begin{tabular}{|c|c|c|c|c|c|c|c|c|c|c|}
\hline & \multicolumn{10}{|c|}{ Dependent variable: } \\
\hline & \multicolumn{5}{|c|}{ Monthly Inflation (NSA) } & \multicolumn{5}{|c|}{ Monthly Inflation } \\
\hline & (1) & (2) & (3) & (4) & (5) & (6) & (7) & (8) & (9) & $(10)$ \\
\hline Non-Border city & $\begin{array}{c}-1.180 \\
(0.990)\end{array}$ & $\begin{array}{c}0.094 \\
(0.073)\end{array}$ & $\begin{array}{c}0.094 \\
(0.071)\end{array}$ & $\begin{array}{c}0.017 \\
(0.025)\end{array}$ & $\begin{array}{c}0.021 \\
(0.031)\end{array}$ & $\begin{array}{c}-0.072 \\
(0.096)\end{array}$ & $\begin{array}{c}-0.024 \\
(0.075)\end{array}$ & $\begin{array}{c}-0.024 \\
(0.074)\end{array}$ & $\begin{array}{c}0.011 \\
(0.023)\end{array}$ & $\begin{array}{c}0.011 \\
(0.023)\end{array}$ \\
\hline VAT 2009 (Dec) & $\begin{array}{l}-1.412 \\
(0.955)\end{array}$ & & & $\begin{array}{l}0.113^{*} \\
(0.060)\end{array}$ & $\begin{array}{c}-0.108 \\
(0.067)\end{array}$ & $\begin{array}{c}0.043 \\
(0.096)\end{array}$ & & & $\begin{array}{c}0.002 \\
(0.061)\end{array}$ & $\begin{array}{c}0.018 \\
(0.058)\end{array}$ \\
\hline Non-Border city * VAT 2009 (Dec) & $\begin{array}{c}1.274 \\
(0.982)\end{array}$ & & & $\begin{array}{c}0.077 \\
(0.068)\end{array}$ & $\begin{array}{c}0.057 \\
(0.061)\end{array}$ & $\begin{array}{c}0.047 \\
(0.100)\end{array}$ & & & $\begin{array}{c}-0.035 \\
(0.066)\end{array}$ & $\begin{array}{c}-0.040 \\
(0.063)\end{array}$ \\
\hline VAT 2010 (Jan) & & $\begin{array}{c}0.623^{* * *} \\
(0.071)\end{array}$ & & $\begin{array}{c}0.736^{* * *} \\
(0.088)\end{array}$ & $\begin{array}{c}-0.482 \\
(0.296)\end{array}$ & & $\begin{array}{c}0.285^{* * *} \\
(0.089)\end{array}$ & & $\begin{array}{c}0.287^{* * *} \\
(0.100)\end{array}$ & $\begin{array}{c}-0.287^{* * *} \\
(0.094)\end{array}$ \\
\hline Non-Border city * VAT 2010 (Jan) & & $\begin{array}{c}0.172 \\
(0.112)\end{array}$ & & $\begin{array}{c}0.249^{* *} \\
(0.116)\end{array}$ & $\begin{array}{l}0.235^{*} \\
(0.122)\end{array}$ & & $\begin{array}{c}0.458^{* * *} \\
(0.123)\end{array}$ & & $\begin{array}{c}0.423^{* * *} \\
(0.122)\end{array}$ & $\begin{array}{c}0.434^{* * *} \\
(0.114)\end{array}$ \\
\hline VAT 2010 (Feb) & & & $\begin{array}{c}0.075 \\
(0.168)\end{array}$ & $\begin{array}{c}0.188 \\
(0.141)\end{array}$ & $\begin{array}{c}-0.228 \\
(0.184)\end{array}$ & & & $\begin{array}{c}0.193 \\
(0.124)\end{array}$ & $\begin{array}{l}0.195^{* *} \\
(0.088)\end{array}$ & $\begin{array}{c}-0.082 \\
(0.085)\end{array}$ \\
\hline Non-Border city * VAT 2010 (Feb) & & & $\begin{array}{c}0.096 \\
(0.176)\end{array}$ & $\begin{array}{c}0.173 \\
(0.148)\end{array}$ & $\begin{array}{c}0.115 \\
(0.149)\end{array}$ & & & $\begin{array}{c}0.161 \\
(0.137)\end{array}$ & $\begin{array}{c}0.126 \\
(0.096)\end{array}$ & $\begin{array}{c}0.133 \\
(0.094)\end{array}$ \\
\hline Cross-section Inflation (NSA) & & & & & $\begin{array}{c}1.295^{* * *} \\
(0.260)\end{array}$ & & & & & \\
\hline Cross-section Inflation & & & & & & & & & & $\begin{array}{c}0.897^{* * *} \\
(0.085)\end{array}$ \\
\hline Constant & $\begin{array}{l}1.678^{*} \\
(0.965)\end{array}$ & $\begin{array}{c}0.267^{* * *} \\
(0.064)\end{array}$ & $\begin{array}{c}0.267^{* * *} \\
(0.064)\end{array}$ & $\begin{array}{c}0.154^{* * *} \\
(0.023)\end{array}$ & $\begin{array}{r}-0.066^{*} \\
(0.034)\end{array}$ & $\begin{array}{l}0.162^{*} \\
(0.093)\end{array}$ & $\begin{array}{c}0.205^{* * *} \\
(0.069)\end{array}$ & $\begin{array}{c}0.205^{* * *} \\
(0.067)\end{array}$ & $\begin{array}{c}0.203^{* * *} \\
(0.021)\end{array}$ & $\begin{array}{c}0.014 \\
(0.030) \\
\end{array}$ \\
\hline
\end{tabular}

Sources: INEGI and authors' calculations.

Notes: Average cross-section inflation is the weighted average of inflation of all the cities. The weights are calculated using the inverse of the Euclidean distance between cities and the own city weight (inverse distance) is set to zero. Block-bootstrap standard errors in parentheses (bootstrap by city with 500 repetitions), ${ }^{*} p<0.10,{ }^{* \star} p<0.05,{ }^{* * *} p<0.01$. 
Appendix Table 5. DID on Inflation for the VAT Reform of 1995 without Center Cities

\begin{tabular}{|c|c|c|c|c|c|c|c|c|c|c|c|c|}
\hline & \multicolumn{12}{|c|}{ Dependent variable: } \\
\hline & \multicolumn{6}{|c|}{ Monthly Inflation (NSA) } & \multicolumn{6}{|c|}{ Monthly Inflation } \\
\hline & (1) & $(2)$ & (3) & (4) & (5) & (6) & (7) & (8) & (9) & $(10)$ & (11) & $(12)$ \\
\hline Non-Border city & $\begin{array}{c}-0.853^{* *} \\
(0.337)\end{array}$ & $\begin{array}{l}-0.483 \\
(0.372)\end{array}$ & $\begin{array}{l}-0.483 \\
(0.372)\end{array}$ & $\begin{array}{l}-0.483 \\
(0.372)\end{array}$ & $\begin{array}{l}-0.207 \\
(0.185)\end{array}$ & $\begin{array}{l}-0.189 \\
(0.207)\end{array}$ & $\begin{array}{c}-1.207^{* * *} \\
(0.337)\end{array}$ & $\begin{array}{c}-0.424 \\
(0.372)\end{array}$ & $\begin{array}{l}-0.424 \\
(0.372)\end{array}$ & $\begin{array}{l}-0.424 \\
(0.372)\end{array}$ & $\begin{array}{l}-0.322 \\
(0.299)\end{array}$ & $\begin{array}{l}-0.371 \\
(0.292)\end{array}$ \\
\hline VAT 1995 (Mar) & $\begin{array}{c}0.840^{* * *} \\
(0.295)\end{array}$ & & & & $\begin{array}{c}3.329^{* * * *} \\
(0.289)\end{array}$ & $\begin{array}{c}0.244 \\
(0.432)\end{array}$ & $\begin{array}{c}0.472 \\
(0.295)\end{array}$ & & & & $\begin{array}{c}3.131^{* * *} \\
(0.371)\end{array}$ & $\begin{array}{c}0.191 \\
(0.412)\end{array}$ \\
\hline Non-Border city * VAT 1995 (Mar) & $\begin{array}{c}0.371 \\
(0.345)\end{array}$ & & & & $\begin{array}{l}-0.276 \\
(0.354)\end{array}$ & $\begin{array}{l}-0.322 \\
(0.361)\end{array}$ & $\begin{array}{l}0.782^{* *} \\
(0.345)\end{array}$ & & & & $\begin{array}{c}-0.102 \\
(0.453)\end{array}$ & $\begin{array}{l}-0.142 \\
(0.425)\end{array}$ \\
\hline VAT 1995 (Apr) & & $\begin{array}{l}0.867^{* *} \\
(0.360)\end{array}$ & & & $\begin{array}{c}4.196^{* * *} \\
(0.131)\end{array}$ & $\begin{array}{c}-0.664 \\
(0.643)\end{array}$ & & $\begin{array}{l}0.672^{*} \\
(0.360)\end{array}$ & & & $\begin{array}{c}3.803^{* * *} \\
(0.359)\end{array}$ & $\begin{array}{l}-0.840 \\
(0.628)\end{array}$ \\
\hline Non-Border city * VAT 1995 (Apr) & & $\begin{array}{c}1.412^{* * *} \\
(0.470)\end{array}$ & & & $\begin{array}{c}1.136^{* * * *} \\
(0.288)\end{array}$ & $\begin{array}{c}1.114^{* * *} \\
(0.323)\end{array}$ & & $\begin{array}{c}1.638^{* * *} \\
(0.470)\end{array}$ & & & $\begin{array}{c}1.536^{* * *} \\
(0.444)\end{array}$ & $\begin{array}{c}1.785^{* * *} \\
(0.466)\end{array}$ \\
\hline VAT 1995 (May) & & & $\begin{array}{c}-2.136^{* * *} \\
(0.425)\end{array}$ & & $\begin{array}{c}1.192^{* * *} \\
(0.208)\end{array}$ & $\begin{array}{l}-0.334 \\
(0.281)\end{array}$ & & & $\begin{array}{c}-1.706^{* * *} \\
(0.425)\end{array}$ & & $\begin{array}{c}1.425^{* * *} \\
(0.210)\end{array}$ & $\begin{array}{l}-0.347 \\
(0.347)\end{array}$ \\
\hline Non-Border city * VAT 1995 (May) & & & $\begin{array}{l}0.854^{*} \\
(0.454)\end{array}$ & & $\begin{array}{l}0.578^{* *} \\
(0.232)\end{array}$ & $\begin{array}{l}0.535^{* *} \\
(0.244)\end{array}$ & & & $\begin{array}{c}0.750 \\
(0.454)\end{array}$ & & $\begin{array}{l}0.648^{* *} \\
(0.254)\end{array}$ & $\begin{array}{l}0.732^{* *} \\
(0.286)\end{array}$ \\
\hline VAT 1995 (Jun) & & & & $\begin{array}{c}-2.848^{* * *} \\
(0.381)\end{array}$ & $\begin{array}{c}0.481^{* * *} \\
(0.154)\end{array}$ & $\begin{array}{l}-0.219 \\
(0.172)\end{array}$ & & & & $\begin{array}{c}-2.671^{* * *} \\
(0.381)\end{array}$ & $\begin{array}{c}0.460 \\
(0.301)\end{array}$ & $\begin{array}{l}-0.453 \\
(0.320)\end{array}$ \\
\hline Non-Border city * VAT 1995 (Jun) & & & & $\begin{array}{c}0.642 \\
(0.427)\end{array}$ & $\begin{array}{l}0.366^{*} \\
(0.209)\end{array}$ & $\begin{array}{l}0.361^{*} \\
(0.217)\end{array}$ & & & & $\begin{array}{c}0.711 \\
(0.427)\end{array}$ & $\begin{array}{l}0.609^{*} \\
(0.349)\end{array}$ & $\begin{array}{l}0.734^{* *} \\
(0.367)\end{array}$ \\
\hline Cross-section Inflation (NSA) & & & & & & $\begin{array}{c}0.979^{* * * *} \\
(0.126)\end{array}$ & & & & & & \\
\hline Cross-section Inflation & & & & & & & & & & & & $\begin{array}{c}0.951^{* * *} \\
(0.114)\end{array}$ \\
\hline Constant & $\begin{array}{c}4.875^{* * *} \\
(0.299) \\
\end{array}$ & $\begin{array}{c}5.715^{* * *} \\
(0.330) \\
\end{array}$ & $\begin{array}{c}5.715^{* * *} \\
(0.330) \\
\end{array}$ & $\begin{array}{c}5.715^{* * *} \\
(0.330) \\
\end{array}$ & $\begin{array}{c}2.386^{* * *} \\
(0.149)\end{array}$ & $\begin{array}{c}0.176 \\
(0.374) \\
\end{array}$ & $\begin{array}{c}5.185^{* * *} \\
(0.299) \\
\end{array}$ & $\begin{array}{c}5.657^{* * *} \\
(0.330) \\
\end{array}$ & $\begin{array}{c}5.657^{* * *} \\
(0.330) \\
\end{array}$ & $\begin{array}{c}5.657^{* * *} \\
(0.330) \\
\end{array}$ & $\begin{array}{c}2.526^{* * *} \\
(0.266) \\
\end{array}$ & $\begin{array}{c}0.359 \\
(0.390)\end{array}$ \\
\hline
\end{tabular}

Sources: INEGI and authors' calculations.

Notes: Average cross-section inflation is a weighted average cross-section inflation rate of the near cities defined in Section II. The weights are calculated using the inverse of the Euclidean distance between cities and the own city weight (inverse distance) is set to zero. Cluster standard errors in parentheses, ${ }^{*} p<0.10,{ }^{* *} p<0.05,{ }^{* \star *} p<0.01$.

The cities included in the sample are: Campeche, Camp.; Chetumal, Q.R.; Mérida, Yuc.; Tapachula, Chis.; Tehuantepec, Oax.; Villahermosa, Tab.; Cd. Acuña, Coah.; Cd. Jimenez, Chih.; Cd. Juárez, Chih.; Culiacan, Sin.; Chihuahua, Chih.; Durango, Dgo.; Hermosillo, Son.; Huatabampo, Son.; La Paz, B.C.S.; Matamoros, Tamps.; Mexicali, B.C.; Monclova, Coah.; Monterrey, N.L.; Tijuana, B.C.; Torreón, Coah. 
Appendix Table 6. DID on Inflation for the VAT Reform of 2010 without Center Cities

\begin{tabular}{|c|c|c|c|c|c|c|c|c|c|c|}
\hline & \multicolumn{10}{|c|}{ Dependent variable: } \\
\hline & \multicolumn{5}{|c|}{ Monthly Inflation (NSA) } & \multicolumn{5}{|c|}{ Monthly Inflation } \\
\hline & (1) & $(2)$ & (3) & $(4)$ & (5) & (6) & $(7)$ & (8) & (9) & $(10)$ \\
\hline \multirow[t]{2}{*}{ Non-Border city } & -0.289 & 0.056 & 0.056 & 0.027 & 0.030 & -0.044 & 0.015 & 0.015 & 0.019 & 0.019 \\
\hline & $(1.214)$ & $(0.084)$ & $(0.084)$ & $(0.033)$ & $(0.038)$ & $(0.101)$ & $(0.074)$ & $(0.074)$ & $(0.031)$ & $(0.032)$ \\
\hline \multirow[t]{2}{*}{ VAT 2009 (Dec) } & -1.412 & & & $0.113^{*}$ & -0.016 & 0.043 & & & 0.002 & 0.007 \\
\hline & $(0.979)$ & & & $(0.057)$ & $(0.066)$ & $(0.088)$ & & & $(0.056)$ & $(0.055)$ \\
\hline \multirow[t]{2}{*}{ Non-Border city * VAT 2009 (Dec) } & 0.345 & & & 0.030 & 0.021 & 0.059 & & & -0.004 & -0.008 \\
\hline & $(1.204)$ & & & $(0.080)$ & $(0.079)$ & $(0.108)$ & & & $(0.065)$ & $(0.064)$ \\
\hline \multirow[t]{2}{*}{ VAT 2010 (Jan) } & & $0.623^{* * *}$ & & $0.736^{* * *}$ & -0.195 & & $0.285^{* * *}$ & & $0.287^{* * *}$ & 0.051 \\
\hline & & $(0.071)$ & & $(0.084)$ & $(0.337)$ & & $(0.093)$ & & $(0.091)$ & $(0.133)$ \\
\hline \multirow[t]{2}{*}{ Non-Border city * VAT 2010 (Jan) } & & 0.258 & & $0.287^{*}$ & 0.290 & & $0.420^{* *}$ & & $0.415^{* *}$ & $0.452^{* *}$ \\
\hline & & $(0.191)$ & & $(0.174)$ & $(0.189)$ & & $(0.201)$ & & $(0.183)$ & $(0.196)$ \\
\hline \multirow[t]{2}{*}{ VAT 2010 (Feb) } & & & 0.075 & 0.188 & -0.002 & & & 0.193 & $0.195^{* *}$ & 0.135 \\
\hline & & & $(0.169)$ & $(0.126)$ & $(0.174)$ & & & $(0.120)$ & $(0.088)$ & $(0.088)$ \\
\hline \multirow[t]{2}{*}{ Non-Border city * VAT 2010 (Feb) } & & & -0.038 & -0.008 & 0.015 & & & -0.037 & -0.041 & -0.043 \\
\hline & & & $(0.194)$ & $(0.146)$ & $(0.167)$ & & & $(0.136)$ & $(0.107)$ & $(0.110)$ \\
\hline \multirow[t]{2}{*}{ Cross-section Inflation (NSA) } & & & & & $1.001^{* * *}$ & & & & & \\
\hline & & & & & $(0.303)$ & & & & & \\
\hline \multirow[t]{2}{*}{ Cross-section Inflation } & & & & & & & & & & $0.376^{* * *}$ \\
\hline & & & & & & & & & & $(0.106)$ \\
\hline \multirow[t]{2}{*}{ Constant } & $1.678^{*}$ & $0.267^{* * *}$ & $0.267^{* * *}$ & $0.154^{* * *}$ & -0.020 & $0.162^{*}$ & $0.205^{* * *}$ & $0.205^{* * *}$ & $0.203^{* * *}$ & $0.123^{* * *}$ \\
\hline & $(0.992)$ & $(0.064)$ & $(0.064)$ & $(0.023)$ & $(0.039)$ & $(0.088)$ & $(0.067)$ & $(0.067)$ & $(0.021)$ & $(0.034)$ \\
\hline
\end{tabular}

Sources: INEGI and authors' calculations.

Notes: Average cross-section inflation is the weighted average of inflation of all the cities. The weights are calculated using the inverse of the Euclidean distance between cities and the own city weight (inverse distance) is set to zero. Cluster standard errors in parentheses, ${ }^{*} p<0.10,{ }^{* \star} p<0.05,{ }^{* \star *} p<0.01$

The cities included in the Clúp. Sin.; Chihuahua, Chih.; Durango, Dgo.; Hermosillo, Son.; Huatabampo, Son.; La Paz, B.C.S.; Matamoros, Tamps.; Mexicali, B.C.; Monclova, Coah.; Monterrey, N.L.; Tijuana, B.C.; Torreón, Coah. 


\section{Appendix Table 7. DID on Inflation for the VAT Reform of 2014 without Center Cities}

\begin{tabular}{|c|c|c|c|c|c|c|c|c|c|c|}
\hline & \multicolumn{10}{|c|}{ Dependent variable: } \\
\hline & \multicolumn{5}{|c|}{ Monthly Inflation (NSA) } & \multicolumn{5}{|c|}{ Monthly Inflation } \\
\hline & (1) & (2) & (3) & (4) & $(5)$ & (6) & (7) & (8) & (9) & $(10)$ \\
\hline Border city & $\begin{array}{c}0.310 \\
(1.415)\end{array}$ & $\begin{array}{c}0.053 \\
(0.131)\end{array}$ & $\begin{array}{c}0.053 \\
(0.131)\end{array}$ & $\begin{array}{c}0.004 \\
(0.037)\end{array}$ & $\begin{array}{c}0.001 \\
(0.036)\end{array}$ & $\begin{array}{c}0.003 \\
(0.113)\end{array}$ & $\begin{array}{c}0.031 \\
(0.114)\end{array}$ & $\begin{array}{c}0.031 \\
(0.114)\end{array}$ & $\begin{array}{l}0.0005 \\
(0.034)\end{array}$ & $\begin{array}{l}0.0005 \\
(0.035)\end{array}$ \\
\hline VAT 2013 (Dec) & $\begin{array}{c}-1.599^{*} \\
(0.914)\end{array}$ & & & $\begin{array}{c}0.145 \\
(0.094)\end{array}$ & $\begin{array}{c}0.002 \\
(0.109)\end{array}$ & $\begin{array}{l}-0.067 \\
(0.078)\end{array}$ & & & $\begin{array}{c}0.044 \\
(0.068)\end{array}$ & $\begin{array}{c}0.044 \\
(0.071)\end{array}$ \\
\hline Border city * VAT 2013 (Dec) & $\begin{array}{c}-0.258 \\
(1.434)\end{array}$ & & & $\begin{array}{c}0.048 \\
(0.149)\end{array}$ & $\begin{array}{c}0.050 \\
(0.156)\end{array}$ & $\begin{array}{c}0.028 \\
(0.149)\end{array}$ & & & $\begin{array}{c}0.030 \\
(0.127)\end{array}$ & $\begin{array}{c}0.030 \\
(0.127)\end{array}$ \\
\hline VAT 2014 (Jan) & & $\begin{array}{c}0.582^{* * *} \\
(0.164)\end{array}$ & & $\begin{array}{c}0.727^{* * *} \\
(0.116)\end{array}$ & $\begin{array}{c}-0.232 \\
(0.366)\end{array}$ & & $\begin{array}{c}0.320^{* * *} \\
(0.118)\end{array}$ & & $\begin{array}{c}0.364^{* * *} \\
(0.085)\end{array}$ & $\begin{array}{l}0.367^{* *} \\
(0.161)\end{array}$ \\
\hline Border city * VAT 2014 (Jan) & & $\begin{array}{c}0.770^{* * *} \\
(0.268)\end{array}$ & & $\begin{array}{c}0.819^{* * *} \\
(0.177)\end{array}$ & $\begin{array}{c}0.835^{\text {*** }} \\
(0.191)\end{array}$ & & $\begin{array}{l}0.615^{*} \\
(0.348)\end{array}$ & & $\begin{array}{l}0.645^{* *} \\
(0.288)\end{array}$ & $\begin{array}{l}0.644^{* *} \\
(0.275)\end{array}$ \\
\hline VAT 2014 (Feb) & & & $\begin{array}{c}-0.115 \\
(0.129)\end{array}$ & $\begin{array}{c}0.030 \\
(0.049)\end{array}$ & $\begin{array}{c}0.051 \\
(0.046)\end{array}$ & & & $\begin{array}{c}-0.098 \\
(0.091)\end{array}$ & $\begin{array}{c}-0.054 \\
(0.043)\end{array}$ & $\begin{array}{c}-0.054 \\
(0.047)\end{array}$ \\
\hline Border city * VAT 2014 (Feb) & & & $\begin{array}{l}-0.222 \\
(0.202)\end{array}$ & $\begin{array}{c}-0.174 \\
(0.147)\end{array}$ & $\begin{array}{l}-0.192 \\
(0.135)\end{array}$ & & & $\begin{array}{l}-0.071 \\
(0.146)\end{array}$ & $\begin{array}{l}-0.040 \\
(0.070)\end{array}$ & $\begin{array}{r}-0.040 \\
(0.069)\end{array}$ \\
\hline Cross-section Inflation (NSA) & & & & & $\begin{array}{c}0.946^{* * *} \\
(0.318)\end{array}$ & & & & & \\
\hline Cross-section Inflation & & & & & & & & & & $\begin{array}{c}-0.004 \\
(0.243)\end{array}$ \\
\hline Constant & $\begin{array}{l}1.963^{* *} \\
(0.878)\end{array}$ & $\begin{array}{c}0.364^{* * *} \\
(0.094)\end{array}$ & $\begin{array}{c}0.364^{* * *} \\
(0.094)\end{array}$ & $\begin{array}{c}0.219^{* * *} \\
(0.015)\end{array}$ & $\begin{array}{c}0.013 \\
(0.068)\end{array}$ & $\begin{array}{c}0.366^{* * *} \\
(0.086)\end{array}$ & $\begin{array}{c}0.299^{* * *} \\
(0.071)\end{array}$ & $\begin{array}{c}0.299^{* * *} \\
(0.071)\end{array}$ & $\begin{array}{c}0.255^{* * *} \\
(0.016)\end{array}$ & $\begin{array}{c}0.256^{* * *} \\
(0.059)\end{array}$ \\
\hline
\end{tabular}

Sources: INEGI and authors' calculations.

Notes: Average cross-section inflation is a weighted average cross-section inflation rate of the near cities defined in Section II. The weights are calculated using the inverse of the Euclidean distance between cities and the own city weight (inverse distance) is set to zero. Cluster standard errors in parentheses, ${ }^{*} \mathrm{p}<0.10,{ }^{* *} \mathrm{p}<0.05,{ }^{* * *} \mathrm{p}<0.01$.

The cities included in the sample are: Campeche, Camp.; Chetumal, Q.R.; Mérida, Yuc.; Tapachula, Chis.; Tehuantepec, Oax.; Villahermosa, Tab.; Cd. Acuña, Coah.; Cd. Jimenez, Chih.; Cd. Juárez, Chih.; Culiacan, Sin.; Chihuahua, Chih.; Durango, Dgo.; Hermosillo, Son.; Huatabampo, Son.; La Paz, B.C.S.; Matamoros, Tamps.; Mexicali, B.C.; Monclova, Coah.; Monterrey, N.L.; Tijuana, B.C.; Torreón, Coah. 
Appendix Table 8. DID on Inflation for the VAT Reform of 2014 without Northern Cities

\begin{tabular}{|c|c|c|c|c|c|c|c|c|c|c|}
\hline & \multicolumn{10}{|c|}{ Dependent variable: } \\
\hline & \multicolumn{5}{|c|}{ Monthly Inflation (NSA) } & \multicolumn{5}{|c|}{ Monthly Inflation } \\
\hline & (1) & $(2)$ & (3) & $(4)$ & $(5)$ & $(6)$ & $(7)$ & $(8)$ & $(9)$ & $(10)$ \\
\hline Border city & $\begin{array}{l}-0.061 \\
(0.271)\end{array}$ & $\begin{array}{c}-0.357^{*} \\
(0.192)\end{array}$ & $\begin{array}{c}-0.357^{*} \\
(0.192)\end{array}$ & $\begin{array}{c}0.112^{* * *} \\
(0.015)\end{array}$ & $\begin{array}{c}0.104^{* * *} \\
(0.020)\end{array}$ & $\begin{array}{c}0.029 \\
(0.207)\end{array}$ & $\begin{array}{c}-0.275^{* * *} \\
(0.099)\end{array}$ & $\begin{array}{c}-0.275^{* * *} \\
(0.099)\end{array}$ & $\begin{array}{c}0.062^{* * *} \\
(0.016)\end{array}$ & $\begin{array}{c}0.057^{* * *} \\
(0.016)\end{array}$ \\
\hline VAT 2013 (Dec) & $\begin{array}{c}0.086 \\
(0.065)\end{array}$ & & & $\begin{array}{c}0.320^{* * *} \\
(0.062)\end{array}$ & $\begin{array}{l}-0.011 \\
(0.074)\end{array}$ & $\begin{array}{c}-0.151^{* * *} \\
(0.051)\end{array}$ & & & $\begin{array}{l}0.078^{*} \\
(0.047)\end{array}$ & $\begin{array}{c}0.014 \\
(0.048)\end{array}$ \\
\hline Border city * VAT 2013 (Dec) & $\begin{array}{c}-0.296^{* * *} \\
(0.106)\end{array}$ & & & $\begin{array}{c}-0.469^{* * *} \\
(0.180)\end{array}$ & $\begin{array}{c}-0.493^{* * *} \\
(0.161)\end{array}$ & $\begin{array}{c}-0.305^{* *} \\
(0.126)\end{array}$ & & & $\begin{array}{c}-0.338^{* * *} \\
(0.088)\end{array}$ & $\begin{array}{c}-0.334^{* * *} \\
(0.085)\end{array}$ \\
\hline VAT 2014 (Jan) & & $\begin{array}{c}0.249^{* *} \\
(0.115)\end{array}$ & & $\begin{array}{c}0.569^{* * *} \\
(0.078)\end{array}$ & $\begin{array}{c}-0.038 \\
(0.100)\end{array}$ & & $\begin{array}{c}0.193^{* *} \\
(0.089)\end{array}$ & & $\begin{array}{c}0.271^{* * *} \\
(0.061)\end{array}$ & $\begin{array}{c}0.016 \\
(0.076)\end{array}$ \\
\hline Border city * VAT 2014 (Jan) & & $\begin{array}{c}1.545^{* * *} \\
(0.451)\end{array}$ & & $\begin{array}{c}1.076^{* * *} \\
(0.272)\end{array}$ & $\begin{array}{c}0.976^{* * *} \\
(0.248)\end{array}$ & & $\begin{array}{c}1.392^{* * *} \\
(0.429)\end{array}$ & & $\begin{array}{c}1.054^{* * *} \\
(0.344)\end{array}$ & $\begin{array}{c}1.062^{* * *} \\
(0.344)\end{array}$ \\
\hline VAT 2014 (Feb) & & & $\begin{array}{c}-0.352^{* * *} \\
(0.079)\end{array}$ & $\begin{array}{c}-0.032 \\
(0.048)\end{array}$ & $\begin{array}{c}0.010 \\
(0.052)\end{array}$ & & & $\begin{array}{c}-0.179^{* * *} \\
(0.058)\end{array}$ & $\begin{array}{c}-0.101^{* *} \\
(0.040)\end{array}$ & $\begin{array}{l}-0.011 \\
(0.041)\end{array}$ \\
\hline Border city * VAT 2014 (Feb) & & & $\begin{array}{l}-0.199 \\
(0.305)\end{array}$ & $\begin{array}{c}-0.668^{* * *} \\
(0.130)\end{array}$ & $\begin{array}{c}-0.630^{* * *} \\
(0.132)\end{array}$ & & & $\begin{array}{c}0.238^{* * *} \\
(0.061)\end{array}$ & $\begin{array}{c}-0.099 \\
(0.102)\end{array}$ & $\begin{array}{l}-0.085 \\
(0.092)\end{array}$ \\
\hline Cross-section Inflation (NSA) & & & & & $\begin{array}{c}1.061^{* * *} \\
(0.125)\end{array}$ & & & & & \\
\hline Cross-section Inflation & & & & & & & & & & $\begin{array}{c}0.839^{* * *} \\
(0.082)\end{array}$ \\
\hline Constant & $\begin{array}{c}0.464^{* * *} \\
(0.045)\end{array}$ & $\begin{array}{c}0.550^{* * *} \\
(0.058)\end{array}$ & $\begin{array}{c}0.550^{* * *} \\
(0.058)\end{array}$ & $\begin{array}{c}0.230^{* * *} \\
(0.009)\end{array}$ & $\begin{array}{c}-0.016 \\
(0.031)\end{array}$ & $\begin{array}{c}0.509^{* * *} \\
(0.035)\end{array}$ & $\begin{array}{c}0.358^{* * *} \\
(0.045)\end{array}$ & $\begin{array}{c}0.358^{* * *} \\
(0.045)\end{array}$ & $\begin{array}{c}0.280^{* * *} \\
(0.009)\end{array}$ & $\begin{array}{c}0.044 \\
(0.028)\end{array}$ \\
\hline
\end{tabular}

Sources: INEGI and authors' calculations.

Notes: Average cross-section inflation is a weighted average cross-section inflation rate of the near cities defined in Section II. The weights are calculated using the inverse of the Euclidean distance between cities and the own city weight (inverse distance) is set to zero. Cluster standard errors in parentheses, ${ }^{*} p<0.10,{ }^{* *} p<0.05,{ }^{* \star *} p<0.01$

The cities excluded in the sample are: Cd. Acuñia, Coah; Cd. Jimenez, Chih; Cd. Juárez, Chih; Culiacan, Sin; Chihuahua, Chih; Durango, Dgo; Hermosillo, Son; Huatabampo, Son; La Paz, BCS; Matamoros, Tamps; Mexicali, BC; Monclova, Coah; Monterrey, NL; Tijuana, BC; Torreón, Coah. 


\section{Appendix Figure 1. Pre-Treatment Trends on Inflation for the VAT Reform of 1995}

(a) Extended DID: Inflation (NSA)

(Percentage points)

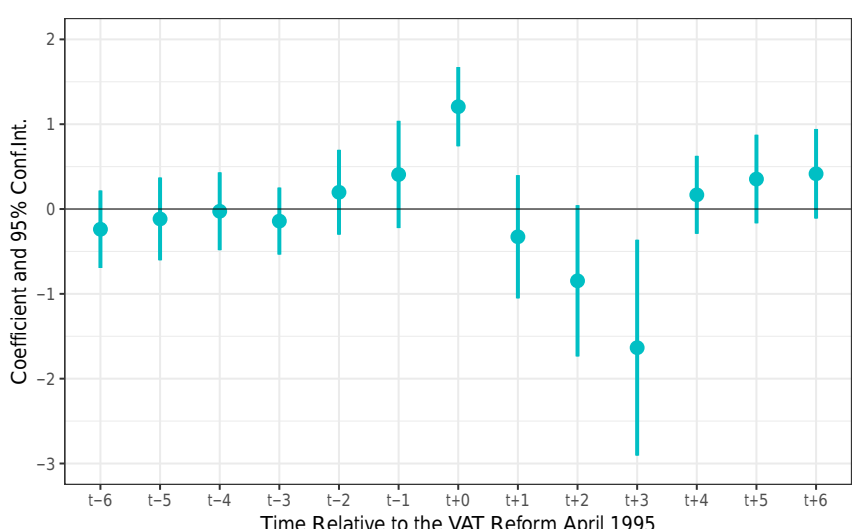

(c) Extended DID: Inflation

(Percentage points)

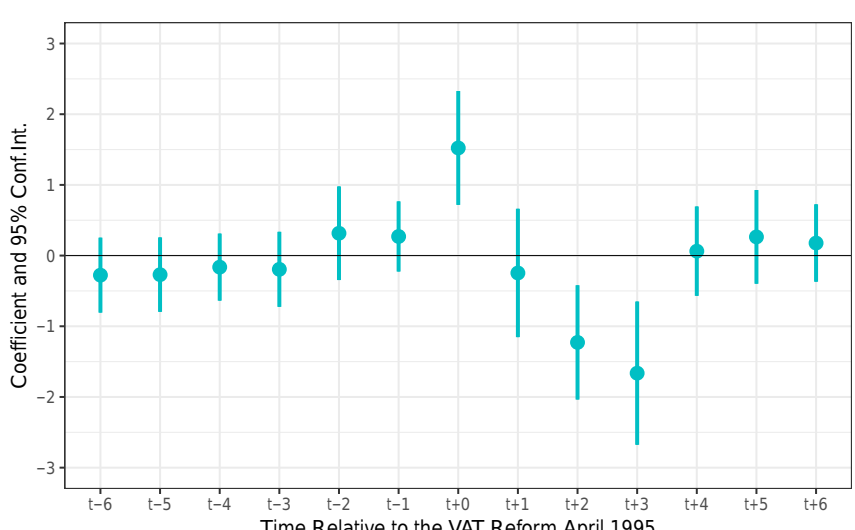

(b) Extended DID: Inflation (NSA) w/CS-Inflation (Percentage points)

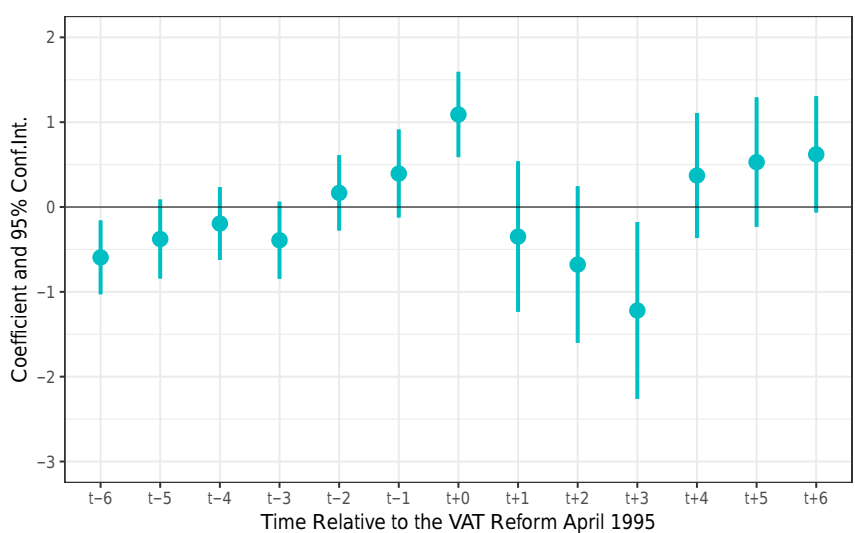

(d) Extended DID: Inflation w/CS-Inflation

(Percentage points)

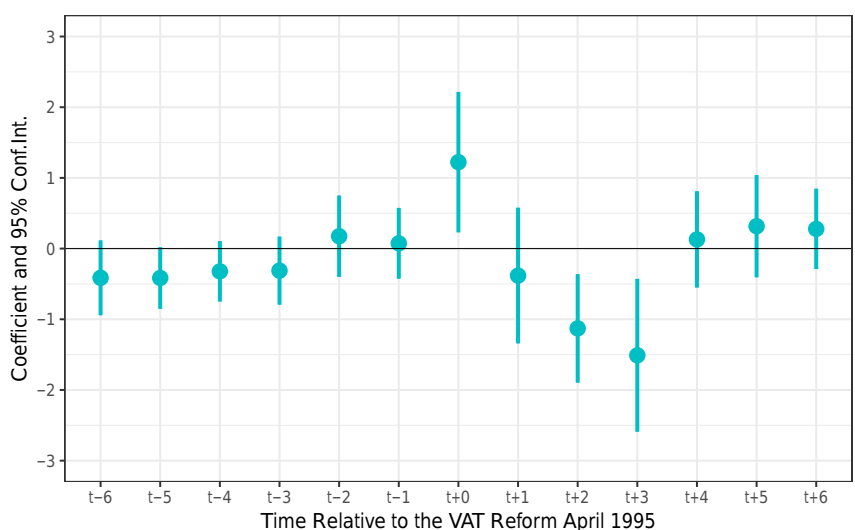

Sources: INEGI and authors' calculations.

Notes: CS-Inflation: regression that includes weighted average cross-section inflation rate of the near cities defined in Section II. The estimation is done with two-way fixed effects regression model with block-bootstrap standard errors by city with 500 repetitions. 


\section{Appendix Figure 2. Pre-Treatment Trends on Inflation for the VAT Reform of 2014}

(a) Extended DID: Inflation (NSA)

(Percentage points)

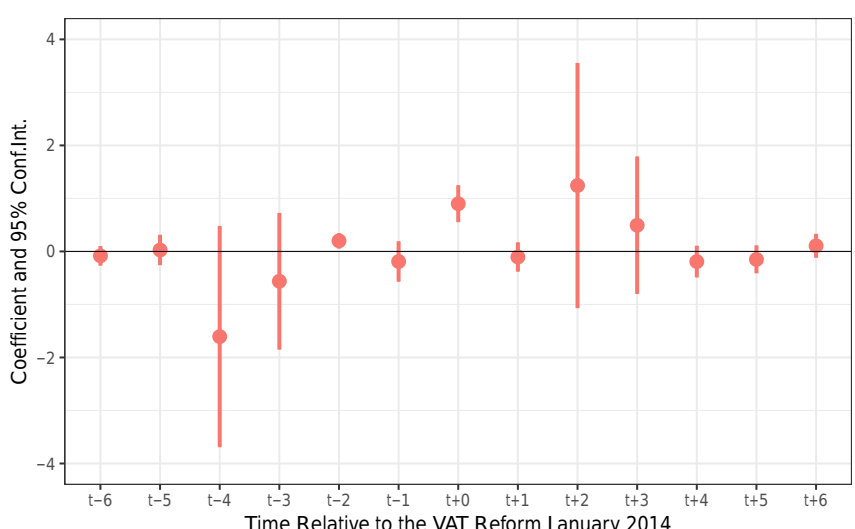

(c) Extended DID: Inflation

(Percentage points)

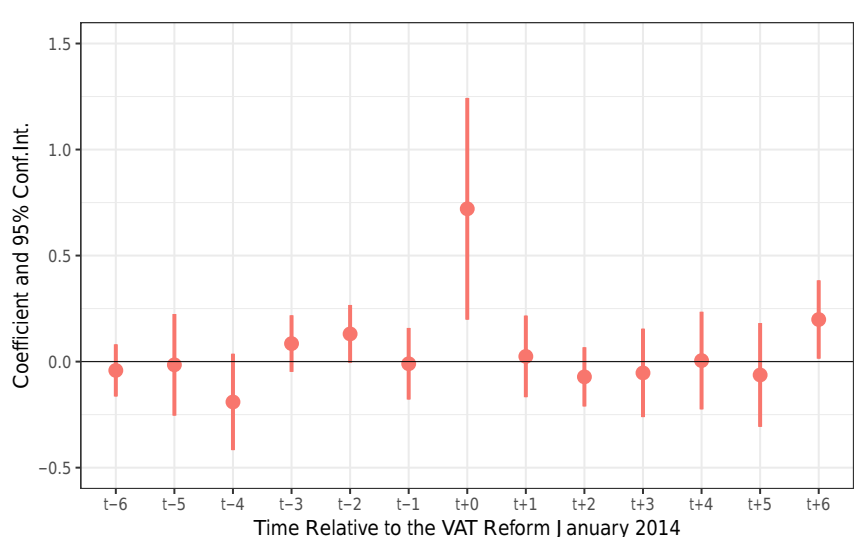

(b) Extended DID: Inflation (NSA) w/CS-Inflation (Percentage points)

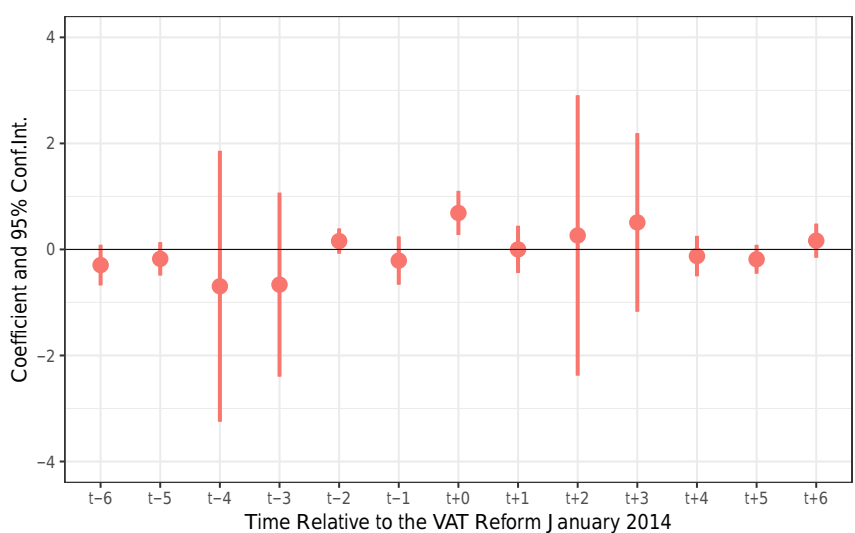

(d) Extended DID: Inflation w/CS-Inflation

(Percentage points)

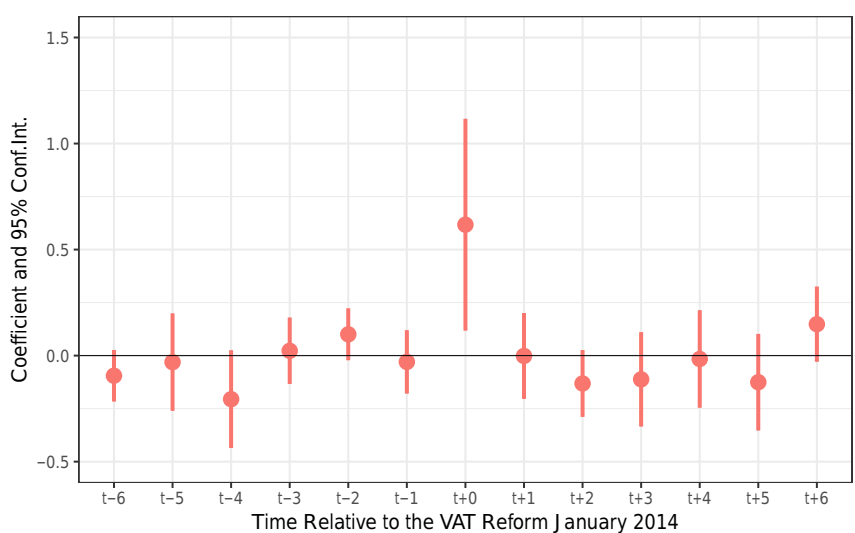

Sources: INEGI and authors' calculations.

Notes: CS-Inflation: regression that includes weighted average cross-section inflation rate of the near cities defined in Section II. The estimation is done with two-way fixed effects regression model with block-bootstrap standard errors by city with 500 repetitions. 


\section{Appendix Table 9. DID Bottom-Up Effect of VAT 2010 (January) on Inflation's Components}

\begin{tabular}{|c|c|c|c|c|c|}
\hline & \multirow[b]{2}{*}{ Count } & \multicolumn{2}{|c|}{ Whole Sample } & \multicolumn{2}{|c|}{ Excluding Center Cities } \\
\hline & & Simple & CS-Inflation & Simple & CS-Inflation \\
\hline \multirow[t]{2}{*}{ Core } & 229 & 0.08 & 0.08 & 0.11 & 0.11 \\
\hline & & $(0.070)$ & $(0.070)$ & $(0.077)$ & $(0.078)$ \\
\hline \multirow[t]{2}{*}{ Merchandise } & 183 & 0.03 & 0.04 & 0.04 & 0.05 \\
\hline & & $(0.084)$ & $(0.083)$ & $(0.089)$ & $(0.090)$ \\
\hline \multirow[t]{2}{*}{ Services } & 46 & $0.26^{\star *}$ & $0.25^{\star *}$ & $0.39^{* *}$ & $0.37^{* *}$ \\
\hline & & $(0.101)$ & $(0.105)$ & $(0.147)$ & $(0.148)$ \\
\hline \multirow[t]{2}{*}{ Non-core } & 53 & $1.46^{\star * *}$ & $0.91^{* *}$ & 0.30 & 0.17 \\
\hline & & $(0.479)$ & $(0.370)$ & $(0.379)$ & $(0.374)$ \\
\hline \multirow[t]{2}{*}{ Agricultural } & 40 & $1.70^{* * *}$ & $0.99^{* *}$ & 0.17 & 0.02 \\
\hline & & $(0.626)$ & $(0.475)$ & $(0.492)$ & $(0.475)$ \\
\hline \multirow[t]{2}{*}{ Energy and Govt. Tariffs } & 13 & $0.71^{\star \star}$ & $0.65^{\star *}$ & $0.67^{*}$ & $0.69^{*}$ \\
\hline & & $(0.258)$ & $(0.264)$ & $(0.310)$ & $(0.330)$ \\
\hline \multirow[t]{2}{*}{ Overall Inflation } & 282 & $0.34^{* * *}$ & $0.24^{* * *}$ & 0.15 & 0.12 \\
\hline & & $(0.111)$ & $(0.090)$ & $(0.095)$ & $(0.093)$ \\
\hline
\end{tabular}

Sources: INEGI and authors' calculations.

Notes: Inflation is seasonally adjusted. Mean group estimation of the DID VAT effect per category: $\widehat{\varphi}=\frac{1}{N} \sum_{i} \widehat{\varphi}_{i}$, as in equation (III.1). The full report of the DID per category is available at the online repository. CS-Inflation: regression that includes weighted average cross-section inflation rate of the near cities defined in Section II. The estimates exclude subway transportation, thus number of subclasses is 282. Standard errors in parentheses: $S E(\widehat{\varphi})=\sqrt{\frac{1}{N(N-1)} \sum_{i}\left(\widehat{\varphi}_{i}-\widehat{\varphi}\right)^{2}}$, and p-values come from a t-distribution: ${ }^{\star} p<0.10,{ }^{\star \star} p<0.05,{ }^{\star \star \star} p<0.01$.

\section{Appendix Table 10. DID Bottom-Up Effect of VAT 2010 (January) on Inflation by VAT-Regime}

\begin{tabular}{|c|c|c|c|c|c|c|}
\hline & \multicolumn{3}{|c|}{ Whole Sample } & \multicolumn{3}{|c|}{ Excluding Center Cities } \\
\hline & Count & Simple & CS-Inflation & Count & Simple & CS-Inflation \\
\hline Zero-Rate & 110 & $\begin{array}{l}0.53^{* *} \\
(0.253)\end{array}$ & $\begin{array}{c}0.27 \\
(0.195)\end{array}$ & 110 & $\begin{array}{c}-0.05 \\
(0.196)\end{array}$ & $\begin{array}{c}-0.11 \\
(0.191)\end{array}$ \\
\hline Taxed & 147 & $\begin{array}{l}0.19^{* *} \\
(0.085)\end{array}$ & $\begin{array}{c}0.20^{\star *} \\
(0.085)\end{array}$ & 147 & $\begin{array}{l}0.26^{\star \star *} \\
(0.097)\end{array}$ & $\begin{array}{c}0.25^{\star \star} \\
(0.098)\end{array}$ \\
\hline Exempt & 25 & $\begin{array}{l}0.33^{* *} \\
(0.149)\end{array}$ & $\begin{array}{c}0.29^{*} \\
(0.149)\end{array}$ & 25 & $\begin{array}{c}0.36^{* *} \\
(0.174)\end{array}$ & $\begin{array}{c}0.37^{\star \star} \\
(0.174)\end{array}$ \\
\hline
\end{tabular}

Sources: INEGI and authors' calculations.

Notes: Inflation is seasonally adjusted. Mean group estimation of the DID VAT effect per category: $\widehat{\varphi}=\frac{1}{N} \sum_{i} \widehat{\varphi}_{i}$, as in equation (III.1). The full report of the DID per category is available at the online repository. CS-Inflation: regression that includes weighted average cross-section inflation rate of the near cities defined in Section II. The estimates exclude subway transportation, thus number of subclasses is 282. Standard errors in parentheses: $S E(\widehat{\varphi})=\sqrt{\frac{1}{N(N-1)} \sum_{i}\left(\widehat{\varphi}_{i}-\widehat{\varphi}\right)^{2}}$, and $\mathrm{p}$-values come from a t-distribution: ${ }^{*} \mathrm{p}<0.10,{ }^{* \star} \mathrm{p}<0.05,{ }^{* \star *} \mathrm{p}<0.01$. 


\section{Appendix Table 11. Probit Model Results}

\begin{tabular}{|c|c|c|c|c|c|c|c|c|c|c|c|c|}
\hline & $\begin{array}{c}(1) \\
d_{i=1}\end{array}$ & $\begin{array}{c}(2) \\
d_{i=2} \\
\end{array}$ & $\begin{array}{c}(3) \\
d_{i=3} \\
\end{array}$ & $\begin{array}{c}(4) \\
d_{i=4}\end{array}$ & $\begin{array}{c}(5) \\
d_{i=5}\end{array}$ & $\begin{array}{c}(6) \\
d_{i=6}\end{array}$ & $\begin{array}{c}(7) \\
d_{i=7}\end{array}$ & $\begin{array}{c}(8) \\
d_{i=8}\end{array}$ & $\begin{array}{c}(9) \\
d_{i=9}\end{array}$ & $\begin{array}{c}(10) \\
d_{i=10} \\
\end{array}$ & $\begin{array}{c}(11) \\
d_{i=11} \\
\end{array}$ & $\begin{array}{c}(12) \\
d_{i=12} \\
\end{array}$ \\
\hline Household scale & $\begin{array}{c}0.495^{\star * *} \\
(0.029)\end{array}$ & $\begin{array}{c}-0.038^{\star * *} \\
(0.012)\end{array}$ & $\begin{array}{c}0.322^{* \star *} \\
(0.011)\end{array}$ & $\begin{array}{c}0.319^{\star * \star} \\
(0.037)\end{array}$ & $\begin{array}{c}0.151^{* * *} \\
(0.011)\end{array}$ & $\begin{array}{c}0.085^{\star \star \star} \\
(0.008)\end{array}$ & $\begin{array}{c}0.187^{\star * \star} \\
(0.010)\end{array}$ & $\begin{array}{c}0.133^{\star * *} \\
(0.009)\end{array}$ & $\begin{array}{c}0.253^{\star * \star} \\
(0.013)\end{array}$ & $\begin{array}{c}0.479^{* * *} \\
(0.009)\end{array}$ & $\begin{array}{l}-0.005 \\
(0.008)\end{array}$ & $\begin{array}{c}0.291^{\star \star *} \\
(0.028)\end{array}$ \\
\hline Age of household head & $\begin{array}{c}-0.003^{* * *} \\
(0.001)\end{array}$ & $\begin{array}{c}0.000 \\
(0.001)\end{array}$ & $\begin{array}{c}-0.019^{* * *} \\
(0.001)\end{array}$ & $\begin{array}{c}0.022^{* * *} \\
(0.002)\end{array}$ & $\begin{array}{c}-0.006^{\star * *} \\
(0.001)\end{array}$ & $\begin{array}{l}-0.001^{*} \\
(0.000)\end{array}$ & $\begin{array}{c}-0.007^{\star * *} \\
(0.001)\end{array}$ & $\begin{array}{c}-0.002^{* * *} \\
(0.001)\end{array}$ & $\begin{array}{c}-0.014^{* * *} \\
(0.001)\end{array}$ & $\begin{array}{c}-0.021^{* * *} \\
(0.001)\end{array}$ & $\begin{array}{c}-0.007^{* * *} \\
(0.000)\end{array}$ & $\begin{array}{c}-0.013^{* * \star} \\
(0.001)\end{array}$ \\
\hline Gender of household head & $\begin{array}{c}-0.218^{* \star *} \\
(0.046)\end{array}$ & $\begin{array}{c}0.314^{\star \star *} \\
(0.028)\end{array}$ & $\begin{array}{c}-0.118^{* \star *} \\
(0.022)\end{array}$ & $\begin{array}{l}-0.003 \\
(0.058)\end{array}$ & $\begin{array}{c}0.027 \\
(0.022)\end{array}$ & $\begin{array}{l}-0.016 \\
(0.018)\end{array}$ & $\begin{array}{c}-0.055^{\star \star \star} \\
(0.021)\end{array}$ & $\begin{array}{c}-0.063^{\star \star \star} \\
(0.021)\end{array}$ & $\begin{array}{l}-0.011 \\
(0.026)\end{array}$ & $\begin{array}{c}-0.118^{\star * \star} \\
(0.020)\end{array}$ & $\begin{array}{c}0.053^{\star \star \star *} \\
(0.018)\end{array}$ & $\begin{array}{l}-0.090^{*} \\
(0.048)\end{array}$ \\
\hline Index of marginalization & $\begin{array}{c}0.018 \\
(0.015)\end{array}$ & $\begin{array}{c}0.189^{\star * \star} \\
(0.010)\end{array}$ & $\begin{array}{c}0.004 \\
(0.007)\end{array}$ & $\begin{array}{c}-0.048^{\star *} \\
(0.020)\end{array}$ & $\begin{array}{c}-0.158^{\star \star *} \\
(0.008)\end{array}$ & $\begin{array}{c}0.048^{* \star *} \\
(0.006)\end{array}$ & $\begin{array}{c}0.211^{* \star *} \\
(0.006)\end{array}$ & $\begin{array}{c}0.411^{* * *} \\
(0.006)\end{array}$ & $\begin{array}{c}0.243^{\star \star *} \\
(0.008)\end{array}$ & $\begin{array}{c}0.064^{\star * \star} \\
(0.006)\end{array}$ & $\begin{array}{c}0.202^{\star * *} \\
(0.006)\end{array}$ & $\begin{array}{l}0.030^{*} \\
(0.016)\end{array}$ \\
\hline Constant & $\begin{array}{c}1.340^{* \star *} \\
(0.113)\end{array}$ & $\begin{array}{c}-2.315^{\star \star *} \\
(0.069)\end{array}$ & $\begin{array}{l}1.179^{* \star *} \\
(0.052)\end{array}$ & $\begin{array}{c}0.893^{\star * *} \\
(0.140)\end{array}$ & $\begin{array}{c}1.579^{\star \star \star} \\
(0.055)\end{array}$ & $\begin{array}{c}-0.379^{* * *} \\
(0.042)\end{array}$ & $\begin{array}{c}-0.142^{\star \star *} \\
(0.047)\end{array}$ & $\begin{array}{c}-1.180^{\star * *} \\
(0.047)\end{array}$ & $\begin{array}{c}0.504^{* \star *} \\
(0.059)\end{array}$ & $\begin{array}{c}-0.685^{\star \star *} \\
(0.045)\end{array}$ & $\begin{array}{c}-0.355^{\star \star \star} \\
(0.043)\end{array}$ & $\begin{array}{c}2.200^{* \star *} \\
(0.122)\end{array}$ \\
\hline Observations & 27,654 & 27,654 & 27,654 & 27,654 & 27,654 & 27,654 & 27,654 & 27,654 & 27,654 & 27,654 & 27,654 & 27,654 \\
\hline Pseudo R2 & 0.0830 & 0.0326 & 0.0858 & 0.0984 & 0.0350 & 0.00427 & 0.0520 & 0.136 & 0.101 & 0.112 & 0.0373 & 0.0721 \\
\hline
\end{tabular}

Sources: INEGI, 2010 Household Survey (ENIGH) and authors' calculations.

Notes: Estimates come from a Probit model, $\operatorname{Pr}\left(d_{i h}=1\right)=\Phi\left(\boldsymbol{z}_{i h}^{\prime} \boldsymbol{\theta}_{i}\right)$, where $d_{i h}=1$ if $w_{i h}$ is greater than zero and $d_{i h}=0$ if $w_{i h}$ is zero. Then $\widehat{R}_{i h}=\phi\left(\boldsymbol{z}_{i h}^{\prime} \widehat{\boldsymbol{\theta}}_{i}\right) / \Phi\left(\boldsymbol{z}_{i h}^{\prime} \widehat{\boldsymbol{\theta}}_{i}\right)$, for a positive expenditure share, and $\widehat{R}_{i h}=\phi\left(\boldsymbol{z}_{i h}^{\prime} \widehat{\boldsymbol{\theta}}_{i}\right) /\left(1-\Phi\left(\boldsymbol{z}_{i h}^{\prime} \widehat{\boldsymbol{\theta}}_{i}\right)\right)$ for a zero expenditure share. $\Phi$ and $\phi$ are the cumulative normal distribution and normal density functions, respectively. The variables included in $\boldsymbol{z}_{i h}$ are the household's size, the composite index of marginalization, the gender of the head of household, and the age of the head of the household. The household's size uses the equivalence scale from the Organization for Economic Cooperation and Development (OECD). This methodology assigns a value of 1 to the first household member, 0.7 to each additional adult, and 0.5 to each child. The marginalization index combines several socio-economic indicators of the household such as access to education, electricity, number of toilets, sewer system, and others. For more detail on the calculations see CONAPO's web page: http://www.conapo.gob.mx/es/CONAPO/Indices_de_ Marginacion. Standard errors in parentheses, ${ }^{*} p<0.10,{ }^{* *} p<0.05,{ }^{* * *} p<0.01$ 


\section{Appendix Table 12. Gamma Matrix of Coefficients from The QUAIDS}

\begin{tabular}{lccccccccccccc}
\hline \hline & 1 & 2 & 3 & 4 & 5 & 6 & 7 & 8 & 9 & 10 & 11 & 12 \\
\hline 1. Food and non-alcoholic beverages & 0.000 & -0.208 & -0.740 & 0.090 & -0.115 & 0.301 & -0.563 & -0.008 & 0.001 & -0.329 & -0.000 & 1.571 \\
2. Alcoholic beverages and tobacco & -0.208 & 0.000 & 0.325 & 0.000 & -0.602 & 0.002 & -0.003 & -1.023 & 0.507 & 0.000 & 0.000 & 1.001 \\
3. Clothing and footwear & -0.740 & 0.325 & 0.000 & 0.000 & 0.000 & 0.311 & -0.780 & -2.888 & 0.305 & -0.305 & -0.080 & 3.851 \\
4. Housing and utilities & 0.090 & 0.000 & 0.000 & 0.000 & -0.003 & -0.259 & 0.131 & 0.000 & 0.002 & 0.017 & 0.000 & 0.022 \\
5. Furniture and house supplies & -0.115 & -0.602 & 0.000 & -0.003 & 0.000 & 0.000 & 0.000 & 1.298 & -0.009 & 0.726 & 0.356 & -1.651 \\
6. Health care & 0.301 & 0.002 & 0.311 & -0.259 & 0.000 & -0.326 & 1.624 & 0.001 & -2.118 & 0.269 & -0.275 & 0.468 \\
7. Transportation & -0.563 & -0.003 & -0.780 & 0.131 & 0.000 & 1.624 & -0.013 & 0.002 & -0.169 & -0.012 & -0.749 & 0.531 \\
8. Communications & -0.008 & -1.023 & -2.888 & 0.000 & 1.298 & 0.001 & 0.002 & 0.000 & -0.286 & -0.012 & 0.285 & 2.631 \\
9. Recreation and cultural activities & 0.001 & 0.507 & 0.305 & 0.002 & -0.009 & -2.118 & -0.169 & -0.286 & 0.014 & 0.947 & 0.942 & -0.137 \\
10. Schooling & -0.329 & 0.000 & -0.305 & 0.017 & 0.726 & 0.269 & -0.012 & -0.012 & 0.947 & 0.000 & 0.000 & -1.301 \\
11. Restaurants and hotels & -0.000 & 0.000 & -0.080 & 0.000 & 0.356 & -0.275 & -0.749 & 0.285 & 0.942 & 0.000 & 0.000 & -0.478 \\
12. Diverse goods and services & 1.571 & 1.001 & 3.851 & 0.022 & -1.651 & 0.468 & 0.531 & 2.631 & -0.137 & -1.301 & -0.478 & -6.507 \\
\hline \hline
\end{tabular}

Sources: INEGI, 2010 Household Survey (ENIGH) and authors' calculations.

Notes: Estimates come from a Quadratic Almost Ideal Demand System (QUAIDS, Equation (IV.1)) using a Non-linear system of Seemingly Unrelated Regressions (NLSUR) with data from the household survey and the $\mathrm{CPI}$ aggregated at 12 categories of expenditure. Standard errors in parentheses, ${ }^{\star} p<0.10,{ }^{\star \star} p<0.05,{ }^{\star \star \star} p<0.01$.

Appendix Table 13. Regression Coefficients from The QUAIDS

\begin{tabular}{|c|c|c|c|c|c|c|c|}
\hline \multicolumn{8}{|c|}{$\begin{array}{l}\text { Demand System } \\
\text { Censored-NLSUR }\end{array}$} \\
\hline$\alpha_{i=1}$ & $\begin{array}{c}0.068^{\star * \star} \\
(0.005)\end{array}$ & $\beta_{i=1}$ & $\begin{array}{c}-0.088^{\star \star *} \\
(0.003)\end{array}$ & $\lambda_{i=1}$ & $\begin{array}{c}-0.006^{\star \star \star} \\
(0.000)\end{array}$ & $\delta_{i=1}$ & $\begin{array}{c}-0.017^{\star \star \star} \\
(0.002)\end{array}$ \\
\hline$\alpha_{i=2}$ & $\begin{array}{c}0.222^{\star \star \star} \\
(0.003)\end{array}$ & $\beta_{i=2}$ & $\begin{array}{c}-0.001^{* *} \\
(0.000)\end{array}$ & $\lambda_{i=2}$ & $\begin{array}{c}-0.000^{\star * *} \\
(0.000)\end{array}$ & $\delta_{i=2}$ & $\begin{array}{c}-0.264^{* \star \star} \\
(0.003)\end{array}$ \\
\hline$\alpha_{i=3}$ & $\begin{array}{c}0.060^{* \star *} \\
(0.002)\end{array}$ & $\beta_{i=3}$ & $\begin{array}{l}-0.000 \\
(0.001)\end{array}$ & $\lambda_{i=3}$ & $\begin{array}{c}-0.000^{* *} \\
(0.000)\end{array}$ & $\delta_{i=3}$ & $\begin{array}{c}-0.031^{* \star \star} \\
(0.001)\end{array}$ \\
\hline$\alpha_{i=4}$ & $\begin{array}{c}0.302^{* * *} \\
(0.006)\end{array}$ & $\beta_{i=4}$ & $\begin{array}{c}0.014^{* \star *} \\
(0.003)\end{array}$ & $\lambda_{i=4}$ & $\begin{array}{c}0.002^{* * *} \\
(0.000)\end{array}$ & $\delta_{i=4}$ & $\begin{array}{c}-0.023^{\star \star \star} \\
(0.003)\end{array}$ \\
\hline$\alpha_{i=5}$ & $\begin{array}{c}0.036^{\star \star *} \\
(0.001)\end{array}$ & $\beta_{i=5}$ & $\begin{array}{c}0.004^{* \star *} \\
(0.001)\end{array}$ & $\lambda_{i=5}$ & $\begin{array}{c}0.000^{\star * *} \\
(0.000)\end{array}$ & $\delta_{i=5}$ & $\begin{array}{r}-0.009^{\star \star \star} \\
(0.001)\end{array}$ \\
\hline$\alpha_{i=6}$ & $\begin{array}{c}0.065^{\star \star \star} \\
(0.002)\end{array}$ & $\beta_{i=6}$ & $\begin{array}{c}0.003^{\star \star \star} \\
(0.001)\end{array}$ & $\lambda_{i=6}$ & $\begin{array}{l}0.000^{\star *} \\
(0.000)\end{array}$ & $\delta_{i=6}$ & $\begin{array}{c}-0.033^{\star \star \star} \\
(0.001)\end{array}$ \\
\hline$\alpha_{i=7}$ & $\begin{array}{c}0.099^{\star * *} \\
(0.003)\end{array}$ & $\beta_{i=7}$ & $\begin{array}{l}0.008^{\star \star \star} \\
(0.002)\end{array}$ & $\lambda_{i=7}$ & $\begin{array}{c}0.000 \\
(0.000)\end{array}$ & $\delta_{i=7}$ & $\begin{array}{r}-0.032^{* \star \star} \\
(0.001)\end{array}$ \\
\hline$\alpha_{i=8}$ & $\begin{array}{c}0.057^{\star \star \star *} \\
(0.002)\end{array}$ & $\beta_{i=8}$ & $\begin{array}{c}0.006^{\star \star \star} \\
(0.001)\end{array}$ & $\lambda_{i=8}$ & $\begin{array}{l}0.000^{*} \\
(0.000)\end{array}$ & $\delta_{i=8}$ & $\begin{array}{c}-0.039^{\star \star \star} \\
(0.001)\end{array}$ \\
\hline$\alpha_{i=9}$ & $\begin{array}{c}0.093^{* \star *} \\
(0.002)\end{array}$ & $\beta_{i=9}$ & $\begin{array}{l}0.015^{\star \star \star} \\
(0.001)\end{array}$ & $\lambda_{i=9}$ & $\begin{array}{c}0.001^{\star \star *} \\
(0.000)\end{array}$ & $\delta_{i=9}$ & $\begin{array}{r}-0.011^{* \star \star} \\
(0.001)\end{array}$ \\
\hline$\alpha_{i=10}$ & $\begin{array}{c}0.172^{\star \star \star} \\
(0.003)\end{array}$ & $\beta_{i=10}$ & $\begin{array}{c}0.023^{\star \star \star} \\
(0.001)\end{array}$ & $\lambda_{i=10}$ & $\begin{array}{c}0.002^{* \star *} \\
(0.000)\end{array}$ & $\delta_{i=10}$ & $\begin{array}{c}-0.090^{\star \star \star} \\
(0.001)\end{array}$ \\
\hline$\alpha_{i=11}$ & $\begin{array}{c}0.122^{\star \star \star} \\
(0.003)\end{array}$ & $\beta_{i=11}$ & $\begin{array}{c}0.009^{\star \star \star} \\
(0.001)\end{array}$ & $\lambda_{i=11}$ & $\begin{array}{c}0.001^{\star \star \star *} \\
(0.000)\end{array}$ & $\delta_{i=11}$ & $\begin{array}{c}-0.058^{* \star \star} \\
(0.001)\end{array}$ \\
\hline$\alpha_{i=12}$ & $\begin{array}{c}-0.297^{\star * *} \\
(0.004)\end{array}$ & $\beta_{i=12}$ & $\begin{array}{l}0.008^{\star \star \star} \\
(0.001)\end{array}$ & $\lambda_{i=12}$ & $\begin{array}{l}-0.000 \\
(0.000)\end{array}$ & $\delta_{i=12}$ & $\begin{array}{c}0.607^{\star \star \star} \\
(0.006)\end{array}$ \\
\hline Observations & 27,654 & & & & & & \\
\hline
\end{tabular}

Sources: INEGI, 2010 Household Survey (ENIGH) and authors' calculations.

Notes: Estimates come from a Quadratic Almost Ideal Demand System (QUAIDS, Equation (IV.1)) using a Non-linear system of Seemingly Unrelated Regressions (NLSUR) with data from the household survey and the CPI aggregated at 12 categories of expenditure. Standard errors in parentheses, ${ }^{*} p<0.10,{ }^{* *} p<0.05,{ }^{* * *} p<0.01$. 


\section{APPENDiX B. TAX InCIDENCE OF THE VAT}

This section illustrates, in the simplest way, the effect of the VAT on the price level. The first part develops the analysis of tax incidence while the second part shows how the analysis is applied to our estimations on the tax incidence.

The partial equilibrium analysis assumes that a tax only affects the price of its own good and the market is small enough that it has no influence on wages, income, or the supply of any other good. In this setup, the market equilibrium is achieved when the quantity supplied equals the quantity demanded. The consumers and the firms face the same price. A new tax, like the VAT, changes the price level and sets a new equilibrium. At the new price, the consumer pays $p_{i}=(1+\tau) q_{i}$, the firms receive $q_{i}$ as before, and the government claims $\tau q_{i}$. The new equilibrium is achieved when the following condition holds:

$$
x_{i}^{S}\left(q_{i}\right)=x_{i}^{D}\left((1+\tau) q_{i}\right)
$$

where $x_{i}^{S}(\cdot)$ and $x_{i}^{D}(\cdot)$ are the supply and demand functions respectively. The effect on the prices does not depend on which side collects the tax. For convenience and to make the formulas more tractable, we assume that the tax is relatively small and it is collected from the consumers. Taking the price $q_{i}$ as a function of the VAT rate, and differentiating B.1 with respect to $\tau$, we get the total derivative:

$$
\frac{\partial x_{i}^{S}\left(q_{i}\right)}{\partial q_{i}} \frac{d q_{i}}{d \tau}=\frac{\partial x_{i}^{D}\left((1+\tau) q_{i}\right)}{\partial q_{i}}\left[\frac{d q_{i}}{d \tau}+q_{i}\right] .
$$

One can simplify the equation by solving for $\frac{d q_{i}}{d \tau}$ and multiply the numerator and denominator with the ratio of prices to quantities, and then, substituting in the formula of price elasticities, giving:

$$
\frac{d q_{i}}{d \tau}=\frac{-q_{i} \eta_{i}^{D}}{\eta_{i}^{S}+\eta_{i}^{D}}=\frac{-q_{i}}{1+\frac{\eta_{i}^{S}}{\eta_{i}^{D}}}
$$

where the demand and supply price elasticities (uncompensated) are defined as $\eta_{i}^{D}=-\frac{\partial x_{i}^{D}}{\partial q_{i}} \frac{q_{i}}{x_{i}}$ and $\eta_{i}^{S}=\frac{\partial x_{i}^{S}}{\partial q_{i}} \frac{q_{i}}{x_{i}}$. Now, to get the consumer price effect, $\frac{d p_{i}}{d \tau}$, one can use derivatives and the 
result in equation B.2 as follows:

$$
\frac{d p_{i}}{d \tau}=\frac{d q_{i}}{d \tau}+q_{i}=\frac{q_{i} \eta_{i}^{S}}{\eta_{i}^{S}+\eta_{i}^{D}}=\frac{q_{i}}{1+\frac{\eta_{i}^{D}}{\eta_{i}^{S}}}
$$

This derivation shows the well-known result that the tax burden is shared between consumers and producers. The amount of the burden shared depends on the relative elasticities of supply and demand; where the more inelastic side bears a higher burden. The formula also shows that the incidence of the VAT to the consumers and the firms is proportional to the pre-tax price.

Finally, one can get the first-order approximation of the change in the consumer price as

$$
\Delta p_{i}=p_{i, 1}-p_{i, 0} \approx \frac{d p_{i}}{d \tau} \Delta \tau=\frac{\varphi}{100} .
$$

\section{APPENDix C. VAT With A Monopolistic Firm}

Let $p=(1+\tau) q$ be the price that consumers face, $\tau$ the VAT rate, and $q$ the price that the monopolistic firm sets. The problem of the firm is to choose a price $q$ that maximizes its benefits.

$$
\max _{q}\{q \cdot x(p)-c(x)\}
$$

Where the first order condition is:

$$
q \cdot \frac{d x}{d p} \cdot(1+\tau)+x(p)-\frac{d c}{d x} \cdot \frac{d x}{d p} \cdot(1+\tau)=0
$$

Now, solving for $p$ we get...

$$
\begin{aligned}
\Rightarrow & \frac{-p}{1+\tau} \cdot \eta^{D} \cdot(1+\tau)+p+M C \cdot \eta^{D} \cdot(1+\tau)=0 \\
\Rightarrow & p \cdot\left(\eta^{D}-1\right)=M C \cdot \eta^{D} \cdot(1+\tau) \\
& \quad p=\frac{M C \cdot(1+\tau)}{1-\frac{1}{\eta^{D}}}
\end{aligned}
$$


where $\eta^{D}=-\frac{d x}{d p} \cdot \frac{p}{x}$ is the (uncompensated) elasticity of demand and $M C$ is the marginal cost of the firm. It turns that the effect of the VAT on the final price depend on the elasticity of demand, and it is proportional to the marginal cost.

As an example, taking a linear supply function, which gives a marginal cost equal to the supply function, Figures 3 and Figures 4 show how a change in the market power and an expansion of the demand affect the final price after a VAT is levied.

\section{Appendix Figure 3. VAT on a Monopolistic Firm with a Decline in Market Power}

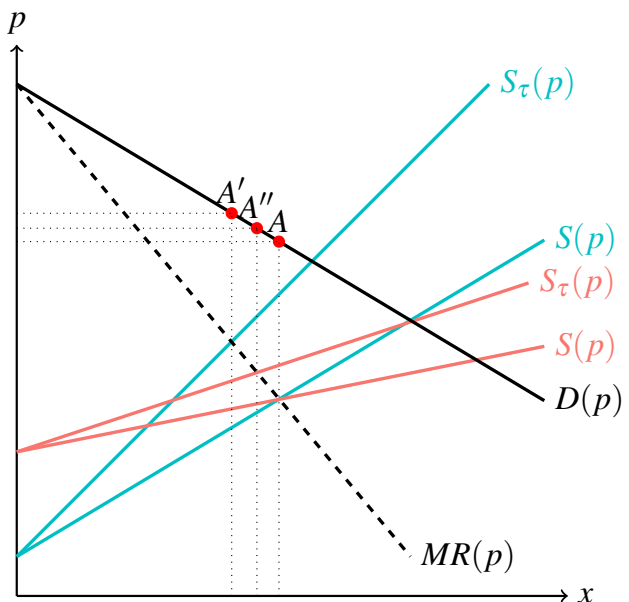

Notes: $D(p)$ is the demand function, $M R(p)$ is the marginal revenue function, $S(p)$ is the supply function, and $S_{\tau}(p)$ is the supply function with the VAT (same rate $\tau$ is applied to both functions).

\section{Appendix Figure 4. VAT on a Monopolistic Firm with an Expansion in Demand}

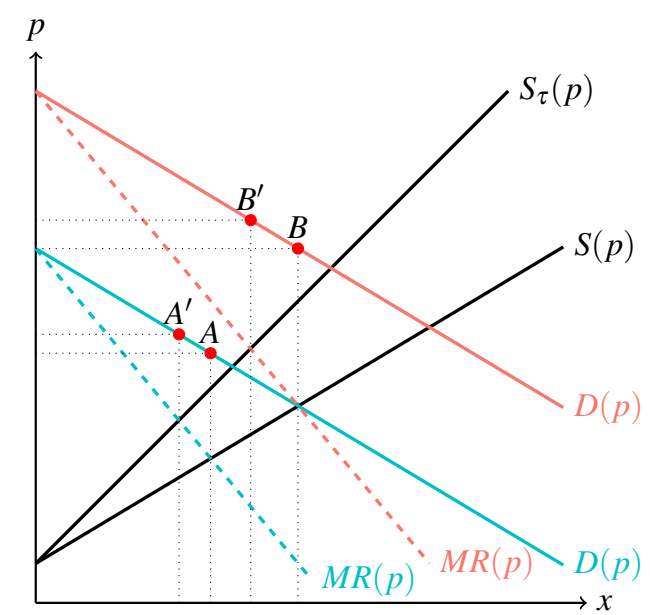

Notes: $D(p)$ is the demand function, $M R(p)$ is the marginal revenue function, $S(p)$ is the supply function, and $S_{\tau}(p)$ is the supply function with the VAT. 